\title{
EFISIENSI DAN EFEKTIFITAS PENGELOLAAN KEUANGAN DAERAH DI PROVINSI PAPUA : SUATU PENERAPAN DATA ENVELOPMENT ANALYSIS DI SEKTOR PENDIDIKAN
}

\author{
Yundy Hafizrianda ${ }^{3}$ \\ hariman.andalan@gmail.com
}

\begin{abstract}
In general, the purpose of this study was to assess the efficiency and effectiveness of Papua province public finance management in education sector. The specific purposes were: a) to describe and analyse the tendency in education sector budgeting as well as the outputs and outcomes of education development in Papua provincial government, regencies/municipality in Papua, and Papua as a whole; and b) to assess and analyse the efficiency of budget expenditures in education sector related to outputs and outcomes from the implementation of education development planning. The analysing tool used to assess efficiency and effectiveness of the regional finance was Data Envelopment Analysis (DEA). $D E A$ is presented with correlation and determinant analysis. The study found that there was none from the 29 regencies/municipality in Papua that was identified to achieve efficiency in spending their expenditures simultaneously. Thus, none of these regencies and municipality was ideal, achieving synergy and integration in regional finance management in education sector. This revealed that the majority of regencies and municipality in Papua province encountered serious problems in managing their public finance particularly in education sector such as planning, budgeting, reporting, controlling, monitoring and evaluating. Another finding also showed that there was inadequate development in public expenditures management to achieve targeted outputs/outcomes such as increasing the ratio of numbers of teacher to students, level of graduates from national final examination, and numbers of school participants. However, there was a declining number of illiteracy and an increase of average length of study as well as number of full participation.
\end{abstract}

Key words: Education sector expenditure, Efficiency, Effectiveness, Data Envelopment Analysis

\section{PENDAHULUAN}

Dalam sepuluh tahun terakhir ini Provinsi Papua mampu menunjukan kinerja perekonomian yang lebih baik dibandingkan

\footnotetext{
${ }^{3}$ Staf dosen Jurusan Ilmu Ekonomi Fakultas Ekonomi Dan Bisnis Universitas Cenderawasih
} 
perekonomian nasional. Sebagai misal laju pertumbuhan ekonomi Papua selama tahun 2004-2014 mencapai 5.72\% per tahun, sedangkan Indonesia sekitar $4.69 \%$ per tahun. Begitu juga dengan laju pertumbuhan pendapatan per kapita Provinsi Papua masih lebih tinggi dibandingkan Indonesia. Bahkan pertumbuhannya sangat mencolok sekitar $8.57 \%$ per tahun, sementara di Indonesia hanya $2.90 \%$ per tahun untuk periode yang sama. Provinsi Papua juga mampu menekan angka pengangguran yang lebih rendah dibandingkan Indonesia, karena mempunyai TPT (Tingkat Pengangguran Terbuka) rata-rata sebesar $5.86 \%$ per tahun. Sementara Indonesia sekitar $7.67 \%$ per tahun untuk periode yang sama.

Kondisi perekonomian Papua yang semakin membaik tersebut ternyata diiringi dengan rendahnya kualitas kinerja pembangunan. Sebagai indikatornya, selama tahun 2002-2014 angka kemiskinan di Papua paling tinggi di Indonesia, mencapai 35,24 \% per tahun, namun dengan kecenderungan yang terus menurun. Kemudian Angka Buta Aksara (ABA) juga paling tinggi sekitar $30,39 \%$ per tahun. Sedangkan Rata-Rata Lama Sekolah paling rendah hanya 6,7 tahun. Demikian pula dengan ketimpangan pendapatan yang diindikatorkan dengan rasio gini termasuk paling tinggi di Indonesia yaitu sebesar 0,43. Semua ini pada akhirnya memberi dampak terhadap rendahnya kualitas pembangunan manusia di Provinsi Papua yang sampai tahun 2014 masih terendah di Indonesia yaitu 56,75, sementara IPM Nasional sudah mencapai 68,90.

Banyak faktor yang menyebabkan mengapa pemerintah Papua belum mampu mempercepat pembangunan manusia selama ini sehingga posisinya sampai sekarang masih tertinggal di Indonesia. Salah satu faktor penyebab utama adalah rendahnya kualitas pembangunan sektor pendidikan. Kondisi ini tercermin misalkan pada APM (Angka Partisipasi Murni) untuk seluruh tingkat pendidikan di Papua paling rendah di Indonesia. Kemudian rasio guru dengan murid, rasio rombel (rombongan belajar), jumlah perpustakaan, ruang laboratorium, dan lain-lain masih jauh dari angka ideal. Seluruh indikator pendidikan ini merupakan 
variabel-variabel yang sangat signifikan mempengaruhi kualitas pembangunan manusia (IPM) Provinsi Papua menjadi paling rendah di tingkat nasional. Selain itu juga merupakan faktor penyebab yang paling dominan membuat kesenjangan pembangunan sosial antar daerah di Provinsi Papua menjadi tinggi. Padahal dana pendidikan yang dikelola selama 14 tahun masa Otonomi Khusus ini cukup tinggi kurang lebih 3,8 triliun rupiah per tahun untuk seluruh kabupaten/kota dan provinsi. Namun hasil yang dicapai dari pengelolaan anggaran pendidikan tersebut tidak maksimal, dan kurang signifikan untuk memperbaiki kinerja pembangunan pendidikan.

Perencanaan pembangunan seharusnya berintegrasi dengan penganggaran, sehingga para perencana pembangunan di Provinsi Papua sepatutnya memiliki kemampuan dan keterampilan teknis yang memadai di bidang teknik-teknik penganggaran. Proses perencanaan pembangunan pendidikan di Provinsi Papua selama ini memang dilakukan melalui jalur dan mekanisme bottom-up (Musrenbang) namun demikian pelaksanaannya belum berjalan baik dan cenderung hanya mengejar output. Selain itu proses perencanaan dan penganggaran pembangunan pendidikan masih tidak tepat waktu, pemenuhan anggaran yang tidak sesuai dengan perencanaan, penentuan prioritas perencanaan dan penganggaran yang belum tepat, dan permasalahanpermasalahan lainnya yang sering kali menyebabkan perencanaan pembangunan yang diterapkan memberi hasil yang kurang tepat sasaran, tidak memenuhi target, melampaui waktu perencanaan, belum optimal, dan sebagainya.

Beranjak kepada kompleksitas permasalahan di atas, maka penting sekali untuk menelusuri dan menganalisis bagaimana sesungguhnya kinerja pengelolaan keuangan daerah di Provinsi Papua selama ini. Apakah sudah efisien dan efektif untuk mencapai sasaran yang telah ditetapkan dalam visi dan misi pembangunan daerah, khususnya pembangunan di sektor pendidikan yang selalu menjadi isu 
sentral dan strategis bagi pemerintah pusat dan pemerintah daerah di Papua.

Terkait dengan latar belakang yang telah disampaikan di atas. tujuan dari studi ini adalah (a) mendeskripsikan dan menganalisis kecenderungan-kecenderungan penganggaran sektor pendidikan, serta output dan outcome pembangunan pendidikan di Papua baik itu pada tingkat provinsi, kabupaten/kota, maupun wilayah Papua secara menyeluruh, dan (b) mengukur dan menganalisis tingkat efisiensi penggunaan anggaran di sektor pendidikan yang dikaitkan dengan output dan outcome dari pelaksanaan perencanaan pembangunan pendidikan.

\section{METODA PENELITIAN}

\section{Analisis Korelasi Dan Determinasi}

Korelasi merupakan teknik analisis yang termasuk dalam salah satu teknik pengukuran asosiasi/hubungan (measures of association). Pengukuran asosiasi merupakan istilah umum yang mengacu pada sekelompok teknik dalam statistik bivariat yang digunakan untuk mengukur kekuatan hubungan antara dua variabel. Diantara sekian banyak teknik- teknik pengukuran asosiasi, terdapat dua teknik korelasi yang sangat populer sampai sekarang, yaitu Korelasi Pearson Product Moment dan Korelasi Rank Spearman. Selain kedua teknik tersebut, terdapat pula teknik-teknik korelasi lain, seperti Kendal, ChiSquare, Phi Coefficient, Goodman-Kruskal, Somer, dan Wilson.

Korelasi bermanfaat untuk mengukur kekuatan hubungan antara dua variabel (kadang lebih dari dua variabel) dengan skala-skala tertentu, misalnya Pearson data harus berskala interval atau rasio; Spearman dan Kendal menggunakan skala ordinal; Chi Square menggunakan data nominal.

Kuat lemahnya hubungan diukur dengan jarak atau range $-1 \leq r \leq 1$. Korelasi mempunyai kemungkinan pengujian hipotesis dua 
arah (two tailed). Korelasi searah jika nilai koefesien korelasi diketemukan positif; sebaliknya jika nilai koefesien korelasi negatif, korelasi disebut tidak searah. Jika koefesien korelasi diketemukan tidak sama dengan nol (0), maka terdapat ketergantungan antara dua variabel tersebut. Jika koefesien korelasi diketemukan +1 . maka hubungan tersebut disebut sebagai korelasi sempurna atau hubungan linear sempurna dengan kemiringan (slope) positif. Jika koefesien korelasi diketemukan -1. maka hubungan tersebut disebut sebagai korelasi sempurna atau hubungan linear sempurna dengan kemiringan (slope) negatif.

Pengukuran korelasi antara dua variabel akan menghasilkan beberapa keputusan yaitu :

- $r=0$

- $0<r<0,25$

- $0,25<r<0,50$

- $0,50<r<0,75$

- $0,75<r<0,99$
(Hubungan kedua variabel tidak ada)

(Hubungan kedua variabel lemah)

(Hubungan kedua variabel cukup kuat)

(Hubungan kedua variabel kuat)

(Hubungan kedua variabel sangat kuat)

Koefisien korelasi atau derajat asosiasi dua peubah (dinotasikan dengan r) dihitung dengan rumus :

$$
r=\frac{n \sum X Y-\sum X \sum Y}{\sqrt{\left[n\left(\sum X^{2}\right)-\left(\sum X\right)^{2}\right]\left[n\left(\sum Y^{2}\right)-\left(\sum Y\right)^{2}\right]}}
$$

Koefisien determinasi pada regresi linear sering diartikan sebagai seberapa besar kemampuan semua variabel bebas dalam menjelaskan varians dari variabel terikatnya. Secara sederhana koefisien determinasi dihitung dengan mengkuadratkan Koefisien Korelasi (R). Sebagai contoh, jika nilai $R$ adalah sebesar 0,80 maka koefisien determinasi ( $R$ Square) adalah sebesar $0,80 \times 0,80=0,64$. Berarti kemampuan variabel bebas dalam menjelaskan varians dari variabel terikatnya adalah sebesar $64,0 \%$. Dengan kata lain terdapat 36\% (100\%$64 \%$ ) varians variabel terikat yang dijelaskan oleh faktor lain. Berdasarkan interpretasi tersebut, maka tampak bahwa nilai $\mathrm{R}^{2}$ adalah antara 0 sampai 
dengan 1. Dimana $R^{2}$ sebesar 1 menunjukan bahwa kemampuan variabel bebas untuk menjelaskan variasi perubahan variabel terikat adalah sebesar $100 \%$, sedangkan jika $R^{2}$ sebesar 0 ini berarti variabel bebas sama sekali tidak memiliki kemampuan $(0 \%)$ untuk menjelaskan variasi dari perubahan variabel terikat.

\section{Data Envelopment Analysis}

Data Envelopment Analysis atau DEA merupakan salah satu tool yang dapat mengukur tingkat relative efisiensi organisasi dengan membandingkan antara input dengan output (Cooper et al, 2002) Sehingga, hasil evaluasinya adalah menentukan tingkat dan nilai efisien dan tidak efisien DMUs. Oleh karena itu, alat ini dapat digunakan untuk mengukur organisasi publik maupun swasta.

DEA bekerja dengan langkah mengidentifikasi unit-unit yang akan dievaluasi, input serta output unit tersebut. Selanjutnya, dihitung nilai produktivitas dan mengidentifikasi unit mana yang tidak menggunakan input secara efisien atau tidak menghasilkan output secara efektif. Produktivitas yang diukur bersifat komparatif atau relatif, karena hanya membandingkan antar unit pengukuran dari 1 set data yang sama. DEA adalah model analisis faktor produksi untuk mengukur tingkat efisiensi relatif dari set unit kegiatan ekonomi (UKE). Skor efisiensi dari banyak fator input dan output dirumuskan sebagai berikut (Talluri, 2000);

Efisiensi $=\frac{\text { Jumlah output tertimbang }}{\text { Jumlah input tertimbang }}$

Dalam DEA, efisiensi relatif UKE didefinisikan sebagai rasio dari total output tertimbang dibagi total input tertimbangya (total weighted output/total weighted input). Inti dari DEA adalah menentukan bobot (weights) atau timbangan untuk setiap input dan output UKE. Bobot tersebut memiliki sifat : (1) tidak bernilai negatif, dan (2) bersifat universal, artinya setiap UKE dalam sampel harus dapat menggunakan seperangkat bobot yang sama untuk mengevaluasi rasionya (total weighted 
output/total weighted input) dan rasio tersebut tidak boleh lebih dari 1 (total weighted output/total weighted input $<1$ ).

Maksimumkan $Z k=\frac{\sum_{r=1}^{s} U r k . Y r k}{\sum_{i=1}^{m} \operatorname{Vik} . X i k}$

Asumsi DEA, tidak ada yang memiliki efisiensi lebih dari $100 \%$ atau 1 , maka formulasinya :

$\frac{\sum_{r=1}^{S} \text { Urk.Yrk }}{\sum_{i=1}^{m} \operatorname{Vik} \cdot X i k} \leq 1, k=1,2,3, \ldots . . n$

Bobot yang dipilih tidak boleh bernilai negatif :

Urk $\geq 0 ; r=1, \ldots . s$

Vik $\geq 0, i=1, \ldots . m$

Transformasi DEA :

Memaksimumkan Zk = $\sum_{r=1}^{s} U r k . Y r k$

Dengan batasan/kendala

$\sum_{r=1}^{s} \operatorname{Urk} . Y r k-\sum_{i=1}^{m} \operatorname{Vik} . X i k \leq 0 ; j=1,2,3, \ldots . n$

$\sum_{i=1}^{m} \operatorname{Vik} . X i k=1,2,3, \ldots . ., n$

Urk $\geq 0 ; r=1,2,3, \ldots ., s$

Vik $\geq 0 ; i=1,2,3, \ldots ., S$

$Y_{\mathrm{rk}} \quad$ : jumlah output $r$ yang dihasilkan oleh UKE $k$

Xik : jumlah input i yang digunakan oleh UKE $k$

S : jumlah output yang dihasilkan

M : jumlah input yang digunakan

$U_{\mathrm{rk}} \quad$ : bobot tertimbang dari output $\mathrm{r}$ yang dihasilkan tiap UKE $\mathrm{k}$

$V_{\mathrm{ik}} \quad$ : bobot tertimbang dari input i yang dihasilkan tiap UKE $\mathrm{k}$

Zk : nilai optimal sebagai indikator efisiensi relatif dari UKE $k$

Data yang digunakan dalam DEA adalah vektor untuk semua UKE yang dianalisa. Dengan menyelesaikan beberapa seri optimasi program linier, DEA mampu mengidentifikasi UKE yang efisien dan sisanya inefisien beserta titik efisien rujukannya. DEA dikembangkan sebagai 
perluasan dari metode rasio teknik klasik untuk efisiensi. DEA menentukan untuk tiap DMU rasio maksimal dari jumlah output yang diberi bobot terhadap jumlah input yang diberi bobot, dengan bobot yang ditentukan oleh model. Dalam mengevaluasi dengan metode DEA, perlu diperhatikan (Haryadi, 2011) :

1. Kebutuhan nilai input dan nilai output untuk masing-masing DMU.

2. DMU memiliki proses yang sama yang menggunakan jenis input dan jenis output yang sama.

3. Mendefinisikan nilai efisiensi relatif masing-masing DMU melalui rasio antara penjumlahan bobot output dengan penjumlahan bobot input.

4. Nilai efisiensi berkisar antara 0 sampai 1.

5. Nilai bobot yang diperoleh dari hasil pemrograman dapat digunakan untuk memaksimumkan nilai efisiensi relatif.

Dalam upaya menjawab tujuan penelitian, model DEA akan digunakan untuk mengkalkulasi efisiensi relatif dari belanja daerah di Papua, dimana unit $k$ adalah Kabupaten/Kota di Provinsi Papua yang diamati untuk dibandingkan. Dalam hal ini jumlah (n) kabupaten/kota yang dinilai dalam analisis sebanyak 29 kab/kota, dengan $i=$ jumlah input yang digunakan sebanyak 1 (satu) yaitu belanja pendidikan, serta $r=$ jumlah output yang dihasilkan oleh kabupaten/kota di bidang pendidikan sebanyak 4 output terdiri atas rasio sekolah terhadap murid dan rasio guru terhadap murid yang merupakan output intermediate, serta Ratarata Lama Sekolah dan Angka Partisipasi Murni yang merupakan outcome.

Variabel input akan dibandingkan dengan variabel output intermediate dan akan menghasilkan nilai efisiensi teknis biaya. Efisiensi teknis biaya merupakan efisiensi dalam penggunaan input berupa belanja pendidikan untuk menghasilkan output berupa fasilitas dan layanan pendidikan. Selanjutnya, variabel output intermediate akan dibandingkan dengan variabel output dan akan menghasilkan nilai efisiensi teknis sistem. Efisiensi teknis sistem adalah efisiensi dalam penggunaan input 
berupa fasilitas dan layanan pendidikan untuk menghasilkan outcome berupa akses pendidikan. Kedua nilai efisiensi tersebut akan terbagi ke dalam dua kondisi, yaitu efisien dan tidak efisien.atau inefisien. Pada kondisi yang tidak efisien akan dilakukan analisis lebih lanjut mengenai besarnya target perbaikan untuk menjadi efisien. Secara singkat kerangka analisis ini dapat dilihat pada Gambar 1.

Gambar 1

Kerangka Analisis Efisien Belanja Sektor Pendidikan Berdasarkan Model Data Envelopment Analysis

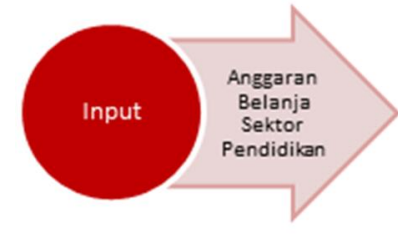

Efisensi Teknis Biaya

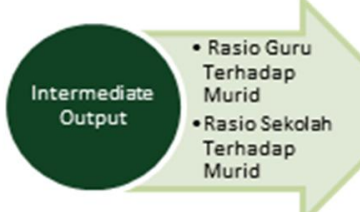

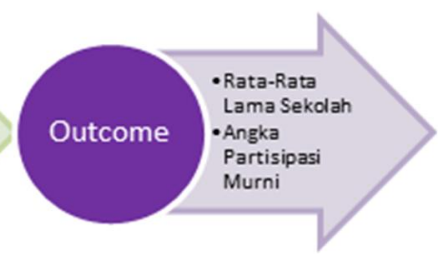

Efisiensi Teknis Sistem

Sumber : data diolah (2015)

\section{HASIL PENELITIAN DAN PEMBAHASAN}

\section{Deskripsi Pembangunan Sektor Pendidikan}

Sebagian besar daerah yang terletak di pegunungan (Kawasan La Pago dan Me Pago) pada umumnya belum dapat menuntaskan program pendidikan dasar sembilan tahun. Seperti yang terlihat selama tahun 2010-2014, rata-rata lama sekolah di daerah-daerah tersebut seperti Kabupaten Nduga, Intan Jaya, Pegunungan Bintang, Deiyai, Yahukimo, Yalimo, Puncak, Tolikara, Mamberamo Tengah, berkisar diantara 1,68 8,63 tahun. Dimana rata-rata lama sekolah yang paling rendah adalah Kabupaten Nduga hanya 1,68 tahun. Sedangkan untuk seluruh daerah di dataran rendah (Kawasan Mamta, Ha'Anim dan Saereri) misalkan Kota Jayapura, Kabupaten Biak Numfor, Merauke, Jayapura, mempunyai ratarata lama sekolah lebih dari 9 tahun, dimana yang paling tinggi di Kota Jayapura yaitu 13,87 tahun, dan Kabupaten Jayapura sebesar 13,11 tahun. 


\section{Gambar 2}

Rata-Rata Lama Sekolah Dan Angka Buta Huruf Di Provinsi Papua Menurut Kabupaten/Kota Rata-Rata Tahun 2010-2014

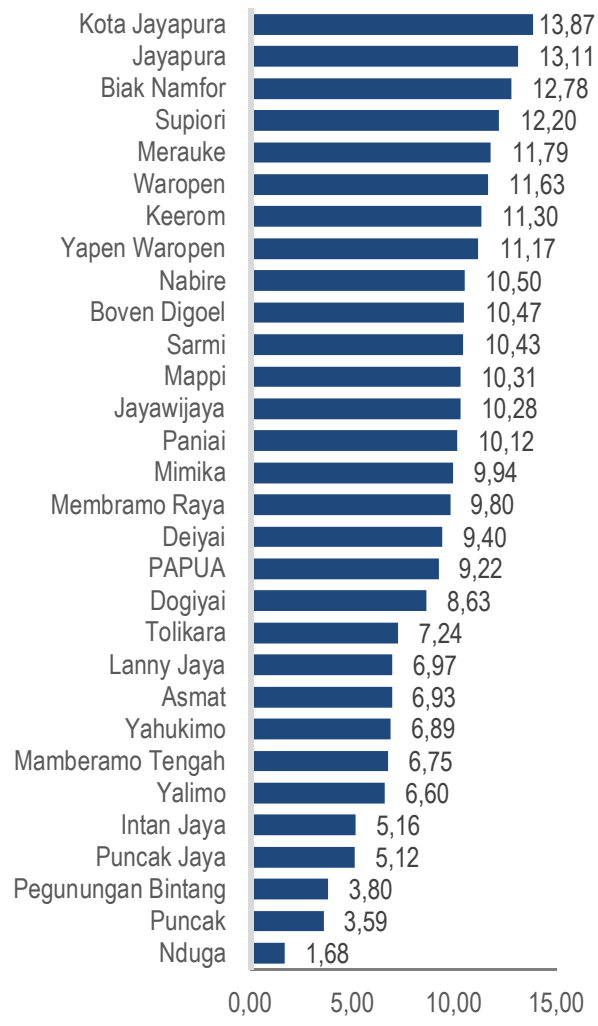

(a) Rata-Rata Lama Sekolah (Tahun)

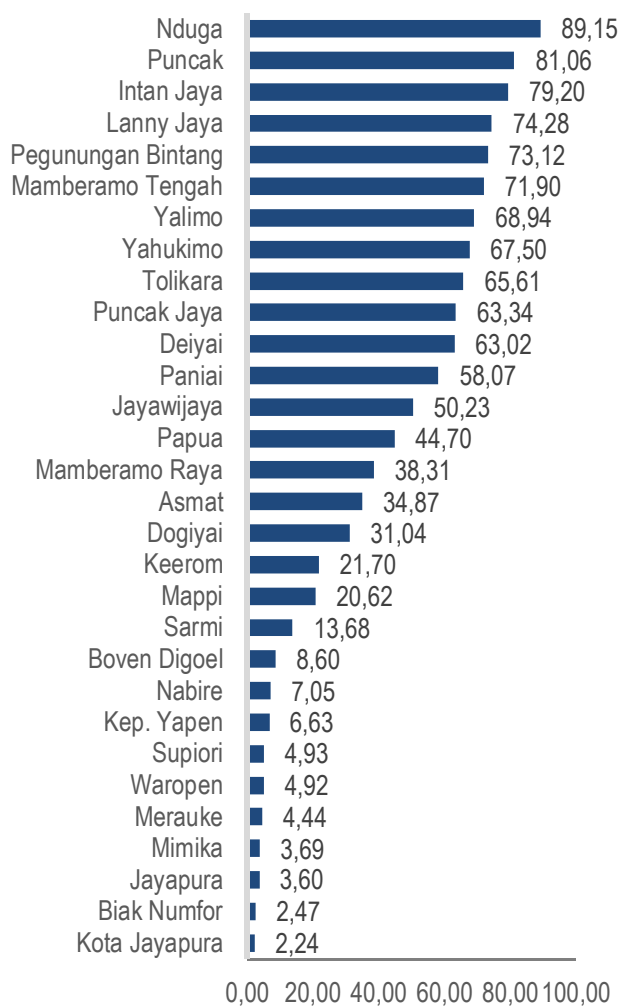

(b) Angka Buta Huruf (\%)

Sumber : BPS Papua, 2015 (data diolah)

Persentase penduduk yang buta huruf di daerah-daerah pegunungan terlihat lebih tinggi dibandingkan penduduk di pesisir dan dataran rendah. Pada sebagian besar daerah pegunungan persentase penduduknya yang buta huruf rata-rata di atas $50 \%$, lebih tinggi dibandingkan Papua. Dimana yang paling tinggi adalah Kabupaten Nduga $(89,15 \%)$ dan Puncak $(81,06 \%)$. Sementara di seluruh daerah pesisir dan dataran mudah akses seperti Kota Jayapura, Kabupaten Merauke, Nabire, Boven Digul, Biak Numfor, Keerom, memiliki persentase penduduk buta huruf rata-rata di bawah $10 \%$, dan jauh lebih rendah dibandingkan Provinsi Papua, terutama di Kota Jayapura, 
Kabupaten Biak Numfor, Mimika, Jayapura, Waropen dan Supiori semuanya mempunyai angka persentase buta huruf di bawah $5 \%$..

Apabila diperhatikan menurut kewilayahan, jumlah penduduk usia sekolah yang mendapat kesempatan untuk bersekolah pada masingmasing kabupaten/kota di Papua cukup tinggi, namun terlihat timpang. Sebagai indikatornya dapat dilihat pada rata-rata APS (Angka Partisipasi Sekolah) masing-masing kabupaten/kota per tahun selama tahun 20122014. APS untuk usia 7-12 rata-rata per tahun sebesar $78,80 \%$ per kabupaten, yang artinya dari total penduduk usia 7-12 tahun di suatu kabupaten sekitar $78,80 \%$ dapat menempuh pendidikan sekolah dasar. Sedangkan untuk APS usia 13-15 setiap tahunnya sebesar 73,95\% per kabupaten. Daerah-daerah yang terletak di pesisir dan dataran rendah yang umumnya memiliki sarana dan prasarana pendidikan cukup memadai terlihat mempunyai APS tinggi diantara $70 \%$ - 90\% untuk seluruh usia pendidikan. Sedangkan di sebagian besar daerah pegunungan mempunyai APS rata-rata di bawah $70 \%$, dimana ada dua daerah yang terindikasi mempunyai APS yang paling rendah yaitu Kabupaten Nduga dan Puncak masing-masing dengan rasio APS yang berkisar antara $21,77 \%$ sampai dengan $27,77 \%$ untuk setiap usia sekolah.

Tabel 1

Angka Partisipasi Sekolah Menurut Usia Pendidikan Dan Kabupaten/Kota

Di Provinsi Papua Tahun 2011-2014

\begin{tabular}{|l|c|c|c|c|c|c|c|c|c|}
\hline \multirow{2}{*}{ Kabupaten/Kota } & \multicolumn{3}{|c|}{2012} & \multicolumn{3}{c|}{2013} & \multicolumn{3}{c|}{2014} \\
\cline { 2 - 11 } & $7-12$ & $13-15$ & $16-18$ & $7-12$ & $13-15$ & $16-18$ & $7-12$ & $13-15$ & $16-18$ \\
\hline Merauke & 92.19 & 86.79 & 61.45 & 91.76 & 89.95 & 66.45 & 96.70 & 94.91 & 80.85 \\
\hline Jayawijaya & 77.96 & 67.75 & 50.34 & 89.74 & 75.02 & 57.63 & 89.58 & 80.82 & 60.50 \\
\hline Jayapura & 94.97 & 85.97 & 83.81 & 96.67 & 93.63 & 78.36 & 97.90 & 99.24 & 87.57 \\
\hline Nabire & 80.74 & 82.83 & 59.02 & 86.10 & 81.61 & 65.56 & 94.97 & 89.24 & 84.73 \\
\hline Kep. Yapen & 94.14 & 87.68 & 71.83 & 90.70 & 91.37 & 73.32 & 93.85 & 93.76 & 79.16 \\
\hline Biak Numfor & 94.19 & 89.06 & 75.00 & 99.41 & 97.09 & 81.86 & 99.20 & 96.72 & 88.15 \\
\hline
\end{tabular}


EFISIENSI DAN EFEKTIFITAS PENGELOLAAN KEUANGAN DAERAH DI PROVINSI PAPUA SUATU PENERAPAN DATA ENVELOPMENT ANALYSIS DI SEKTOR PENDIDIKAN

\begin{tabular}{|c|c|c|c|c|c|c|c|c|c|}
\hline \multirow{2}{*}{ Kabupaten/Kota } & \multicolumn{3}{|c|}{2012} & \multicolumn{3}{|c|}{2013} & \multicolumn{3}{|c|}{2014} \\
\hline & $7-12$ & $13-15$ & $16-18$ & $7-12$ & $13-15$ & $16-18$ & $7-12$ & $13-15$ & $16-18$ \\
\hline Paniai & 84.72 & 81.39 & 61.37 & 77.10 & 84.32 & 40.67 & 85.11 & 90.06 & 63.48 \\
\hline Puncak Jaya & 66.11 & 69.39 & 25.51 & 43.71 & 45.28 & 28.08 & 66.60 & 52.44 & 36.43 \\
\hline Mimika & 88.79 & 79.81 & 57.12 & 97.14 & 89.50 & 66.61 & 99.05 & 91.41 & 77.32 \\
\hline Boven Digoel & 85.42 & 80.27 & 48.48 & 84.74 & 82.69 & 70.05 & 88.88 & 90.07 & 76.07 \\
\hline Mappi & 88.72 & 74.20 & 31.66 & 89.61 & 86.82 & 37.53 & 88.98 & 91.07 & 47.30 \\
\hline Asmat & 62.33 & 44.08 & 23.98 & 58.09 & 72.63 & 17.14 & 70.19 & 78.56 & 30.11 \\
\hline Yahukimo & 67.61 & 51.63 & 41.44 & 32.79 & 38.39 & 21.31 & 54.34 & 53.99 & 38.20 \\
\hline Pegunungan Bintang & n.a & n.a & n.a & 43.58 & 44.10 & 8.62 & 53.18 & 42.00 & 15.70 \\
\hline Tolikara & 65.44 & 78.24 & 33.88 & 70.67 & 66.54 & 49.69 & 79.92 & 79.23 & 63.84 \\
\hline Sarmi & 82.66 & 80.01 & 58.68 & 86.04 & 84.34 & 63.26 & 91.33 & 95.81 & 65.33 \\
\hline Keerom & 69.52 & 66.51 & 55.00 & 84.56 & 88.22 & 83.60 & 94.58 & 91.03 & 86.44 \\
\hline Waropen & 90.48 & 89.50 & 53.44 & 88.69 & 90.60 & 89.66 & 97.14 & 96.12 & 89.18 \\
\hline Supiori & 88.89 & 79.75 & 61.44 & 99.00 & 97.53 & 70.45 & 99.74 & 100.00 & 83.70 \\
\hline Mamberamo Raya & 77.98 & 50.84 & 28.30 & 95.10 & 98.43 & 60.83 & 92.51 & 88.93 & 63.75 \\
\hline Nduga & 22.02 & 13.63 & 1.80 & 24.29 & 25.00 & 12.55 & 34.96 & 31.70 & 29.99 \\
\hline Lanny Jaya & 71.91 & 61.93 & 28.68 & 71.12 & 64.41 & 35.13 & 69.53 & 61.28 & 40.29 \\
\hline Mamberamo Tengah & 71.83 & 49.86 & 33.88 & 85.77 & 72.30 & 45.23 & 86.56 & 68.46 & 39.07 \\
\hline Yalimo & 74.56 & 52.47 & 25.21 & 93.60 & 72.21 & 44.38 & 94.73 & 78.43 & 49.04 \\
\hline Puncak & 37.74 & 20.48 & 23.86 & 31.58 & 34.80 & 27.07 & 31.17 & 23.84 & 19.43 \\
\hline Dogiyai & 81.72 & 70.42 & 48.20 & 89.21 & 86.57 & 65.89 & 89.65 & 90.85 & 68.71 \\
\hline Intan Jaya & 58.52 & 45.82 & 22.12 & 60.05 & 53.98 & 39.09 & 68.42 & 56.42 & 42.09 \\
\hline Deiyai & 87.97 & 89.04 & 68.32 & 90.58 & 68.72 & 61.15 & 93.30 & 87.41 & 75.70 \\
\hline Kota Jayapura & 97.32 & 99.52 & 77.76 & 98.63 & 92.65 & 68.03 & 98.34 & 99.43 & 80.74 \\
\hline Papua & 75.34 & 68.99 & 50.66 & 75.51 & 73.27 & 53.28 & 80.69 & 78.07 & 61.63 \\
\hline
\end{tabular}

Sumber : BPS Papua, 2015 (data diolah) 


\section{Gambar 3}

Rasio Guru Terhadap Murid Pada Jenjang Pendidikan 9 Tahun

Di Provinsi Papua Rata-rata Tahun 2012-2014

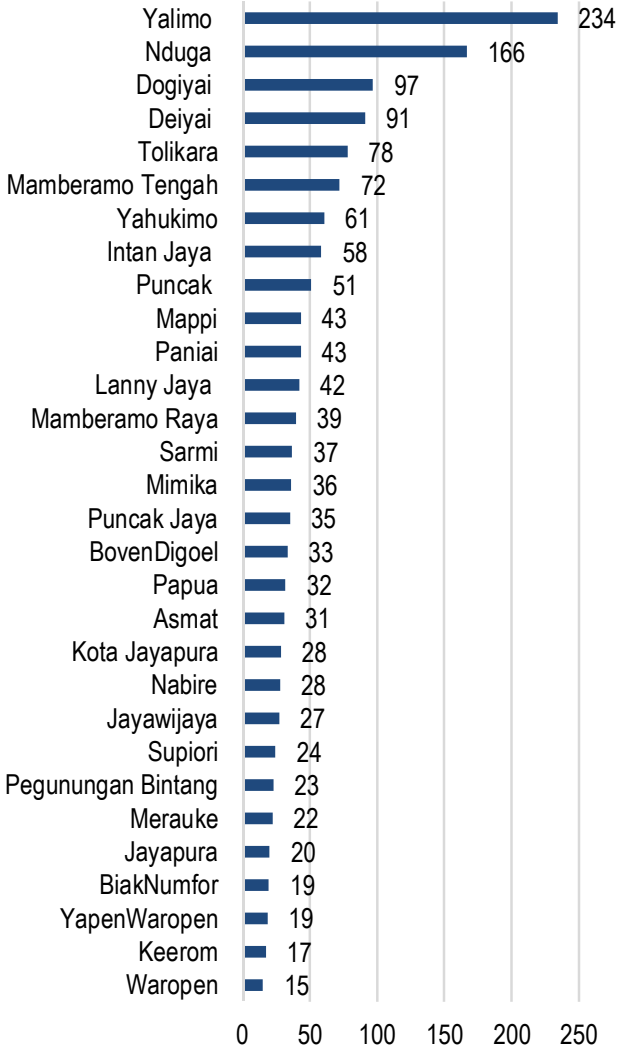

(a) Rasio Guru Murid SD

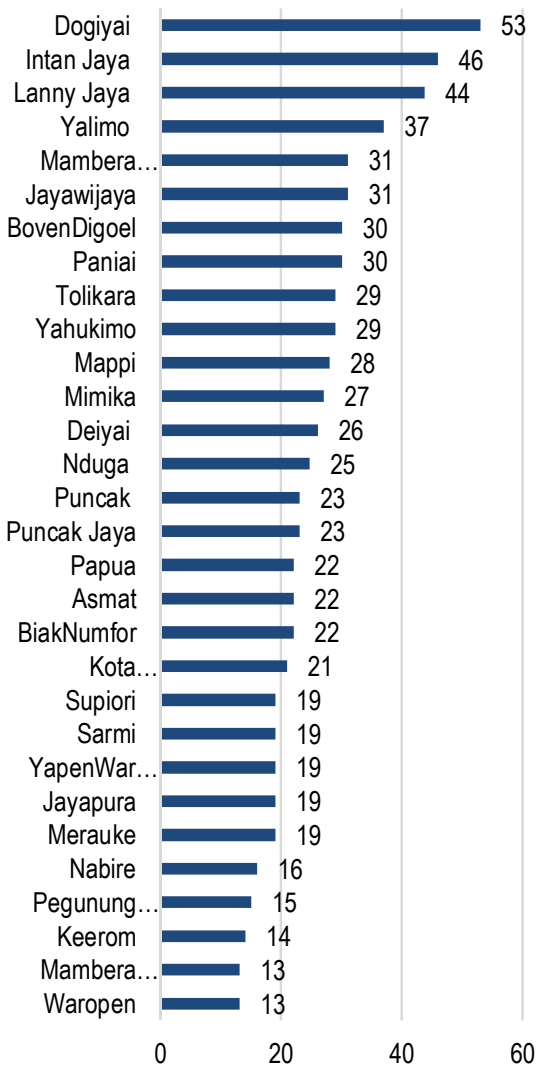

(b) Rasio Guru Murid SMP

Sumber : BPS Papua, 2015 (data diolah)

Sebagian besar kabupaten yang berada di daerah pedalaman dan pegunungan memiliki rasio guru terhadap murid di tingkat SD yang melebihi batas maksimal Standar Pendidikan Nasional. Selama tahun 2012-2014 rata-rata rasionya sebesar 42 murid per guru per tahun. Bahkan untuk Kabupaten Yalimo dan Nduga mencapai 234 dan 166 murid per guru per tahun. Akan tetapi untuk jenjang pendidikan SMP secara rata-rata seluruh kabupaten/kota di Papua mempunyai rasio yang cukup ideal. Hanya sedikit yang mempunyai rasio guru terhadap murid di atas batas maksimal, yaitu Kabupaten Dogiyai, Intan Jaya, Lanny Jaya, 
Yalimo, Mamberamo Tengah, dan Jayawijaya, dengan rata-rata di atas $30 \%$ per tahun.

\section{Kinerja Belanja Pembangunan Di Sektor Pendidikan}

Anggaran belanja untuk pembangunan sektor pendidikan di Papua cukup besar. Selama tahun 2012-2014 misalnya, realisasi belanja di sektor pendidikan bisa mencapai Rp. 3.808,25 milyar per tahun yang berasal dari kabupaten/kota sebanyak Rp. 3.675,03 milyar atau 96,50\% per tahun dari total belanja pendidikan di Papua, dan pemerintah provinsi sebanyak Rp. 133,23 milyar atau 3,50\% per tahun. Anggaran yang cukup besar tersebut dimaksudkan untuk meningkatkan kualitas pembangunan pendidikan di Papua, dengan pembagian kewenangannya masingmasing untuk kabupaten/kota dan provinsi. Selain menggunakan dana APBD, pembangunan pendidikan di Provinsi Papua juga bersumber pada APBN melalui pemberian Dana Dekonsentrasi untuk membiayai kegiatan-kegiatan nonfisik, dan Dana Tugas Pembantuan untuk membiayai kegiatan-kegiatan fisik di sektor pendidikan.

\section{Gambar 4}

Belanja Sektor Pendidikan Kabupaten/Kota Dan Provinsi Di Papua

Tahun 2012-2014

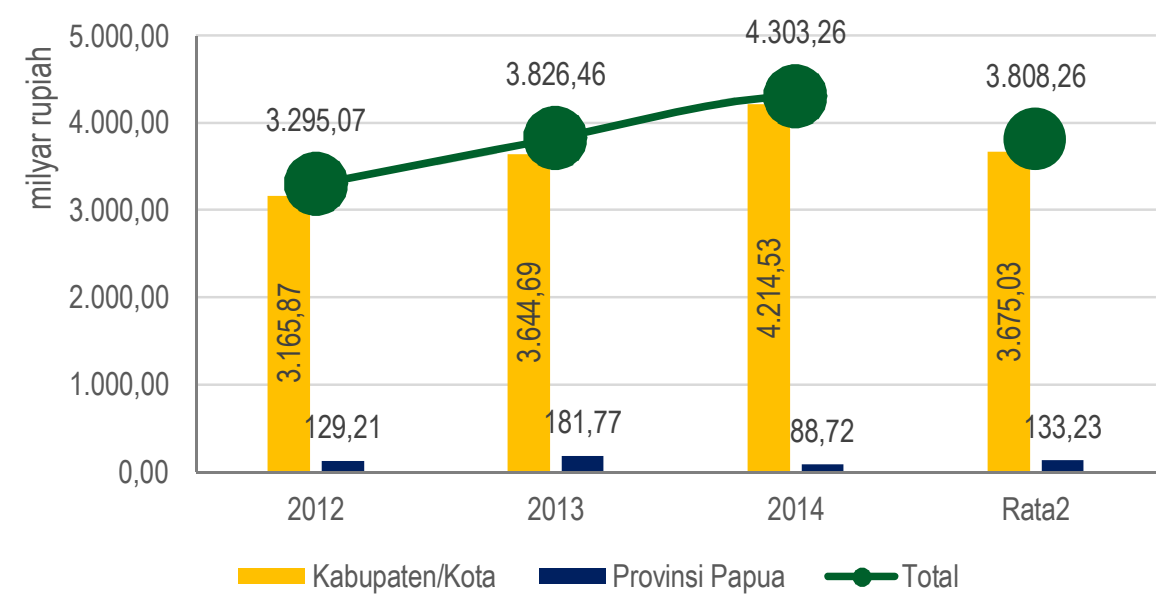

Sumber data : DJPK dan APBD Papua, 2015 (data di olah) 
Belanja sektor pendidikan di Papua cenderung mengalami pertumbuhan yang agak lambat. Rata-rata pertumbuhan belanja sektor pendidikan di tingkat kabupaten/kota hanya sekitar 3,23\% per tahun selama tahun 2012-2014. Sedangkan untuk provinsi mencapai 6,69\% per tahun. Upaya untuk meningkatkan kualitas kinerja pelayanan publik di sektor pendidikan sepertinya belum maksimal dilakukan oleh seluruh pemerintah daerah di Papua.

Jika dilihat menurut kabupaten/kota, terdapat tiga daerah yang memiliki belanja sektor pendidikan paling besar di Papua yaitu Kota Jayapura, Kabupaten Mimika dan Kabupaten Merauke. Rata-rata belanja sektor pendidikan pada ketiga daerah tersebut selama tahun 2012-2014 lebih dari Rp. 220 milyar per tahun. Paling tinggi adalah Kota Merauke mencapai Rp. 315.767,69 juta per tahun. Selain itu yang cukup tinggi juga adalah Kabupaten Biak Numfor, Jayapura, Jayawijaya, Kepulauan Yapen, dan Nabire. Ada indikasi bahwa daerah-daerah yang mudah aksesnya mempunyai nilaii belanja sektor pendidikan paling besar di Papua.

\section{Gambar 5}

Rata-rata Belanja Sektor Pendidikan Menurut Kabupaten/Kota Di Provinsi Papua Tahun 2012-2014

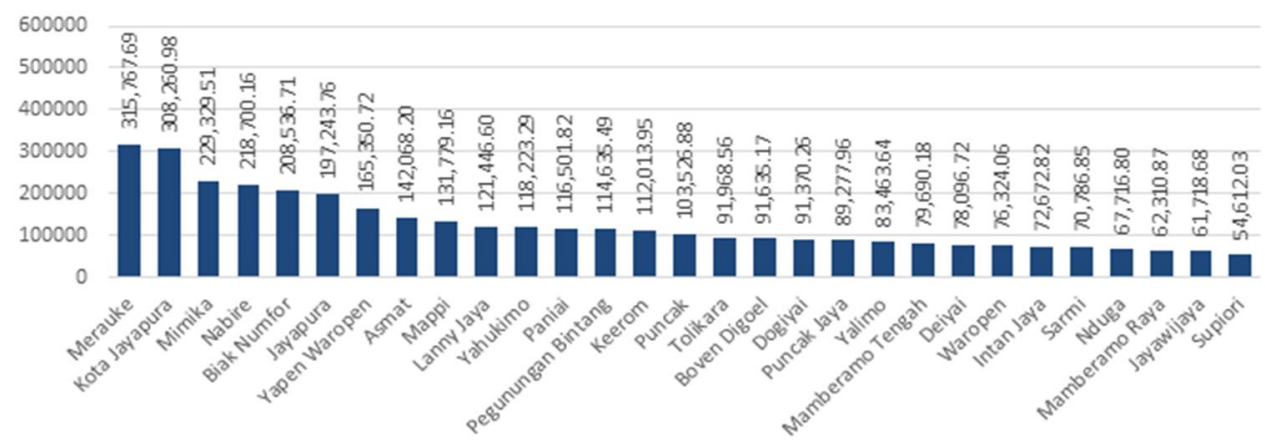

Sumber data : DJPK dan APBD Papua, 2015 (data di olah)

Adapun untuk daerah-daerah lainnya yang sebagian besar terletak di daerah pegunungan dan dataran sulit akses mempunyai 
belanja sektor pendidikan yang rendah. Seperti Kabupaten Puncak Jaya, Dogiyai, Yahukimo yang terletak di pegunungan, dan Kabupaten Asmat, Mamberamo Raya, Supiori, yang terletak di dataran sulit akses, semua daerah tersebut mempunyai porsi belanja di sektor pendidikan tidak lebih dari Rp. 100 milyar pertahun, akan tetapi tidak kurang dari Rp. 50 milyar rupiah per tahun. Kondisi topografi yang sulit ditambah dengan komitmen pemerintah kabupaten terhadap pembangunan pendidikan yang belum maksimal menyebabkan besaran belanja di sektor pendidikan tampaknya sangat rendah.

Porsi belanja sektor pendidikan dalam komposisi anggaran pemerintah daerah di Papua belum memenuhi amanat dari undangundang pendidikan maupun Otsus. Secara keseluruhan terlihat rata-rata alokasi belanja sektor pendidikan di Papua hanya mencapai $10,49 \%$ per tahun, namun dengan kecenderungan yang semakin meningkat. Secara terpisah dapat diperhatikan bahwa alokasi belanja pendidikan di pemerintahan Kabupaten/ Kota lebih baik dibandingkan provinsi, namun masih belum memenuhi amanat undang-undang oleh karena rata-rata per tahun hanya sebesar $13,14 \%$.

Walaupun secara keseluruhan terlihat rendah, akan tetapi jika diamati pada masing-masing kabupaten ada sebagian daerah yang telah memenuhi amanat undang-undang. Terutama jika berpedoman pada undang-undang pendidikan, beberapa daerah seperti Kota Jayapura, Kabupaten Kepulauan Yapen dan Biak Numfor, ketiganya memiliki alokasi belanja pendidikan yang memenuhi amanat yaitu minimal $20 \%$ dari APBD. Kota Jayapura rata-rata mengalokasikan belanja pendidikannya sekitar $28,37 \%$ per tahun dengan maksimal yang pernah dicapai sebesar $36,74 \%$ (melebihi amanat UU Otsus), Kabupaten Kepulauan Yapen rata-rata sebesar 22,23\% per tahun dan maksimal sebesar $25,81 \%$, serta Biak Numfor rata-rata sebesar $22,38 \%$ per tahun dan maksimal sebesar $29,48 \%$. 
Gambar 6

Rasio Belanja Sektor Pendidikan Terhadap Total Belanja Daerah

Di Provinsi Papua dan Kabupaten/Kota Tahun 2012-2014

(dalam \%)

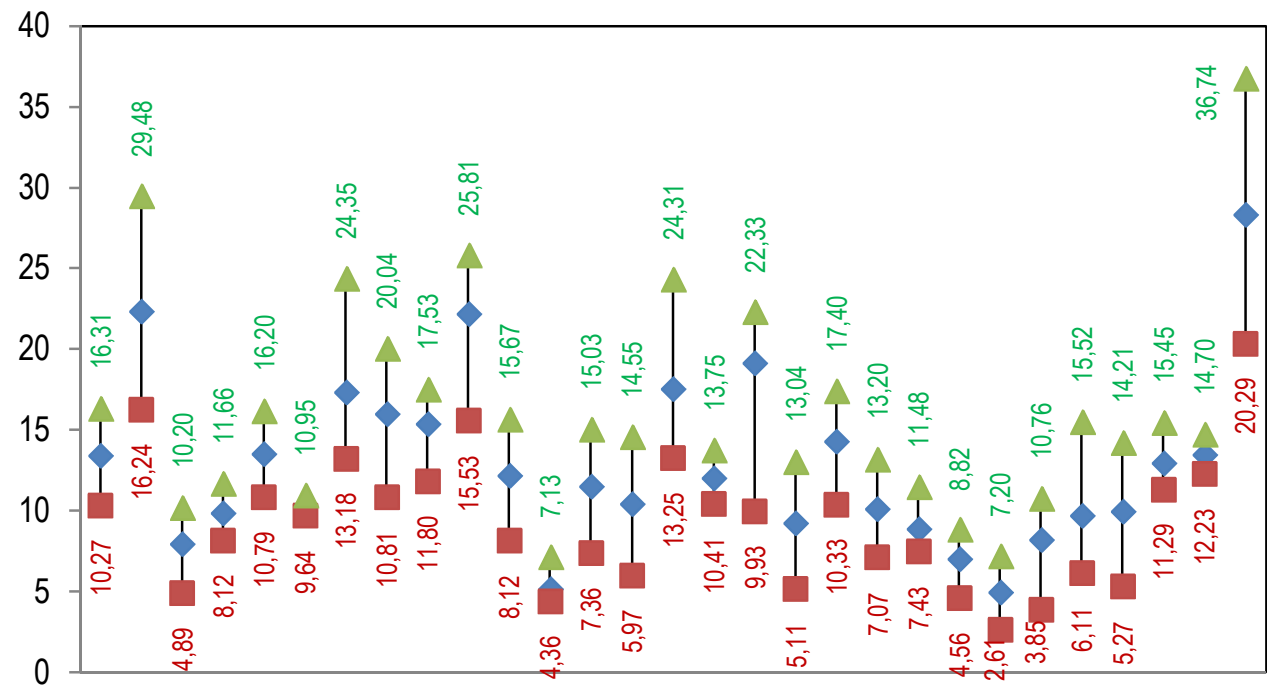

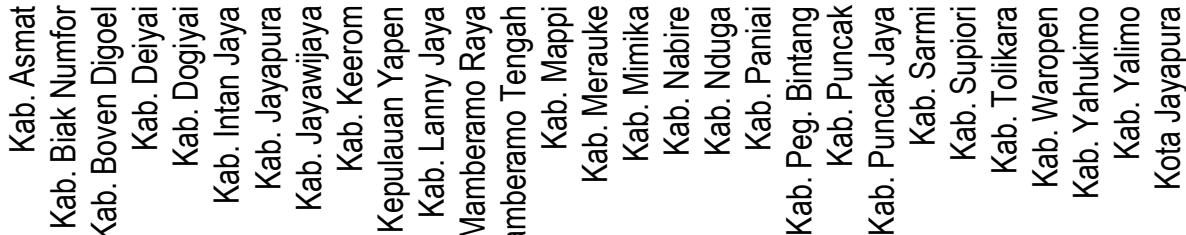

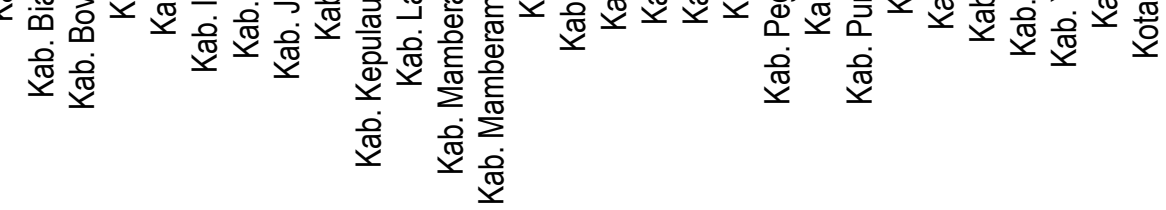

$\diamond$ Rata-rata $\square \min \Delta \max$

Sumber data : DJPK dan APBD Papua, 2015 (data di olah)

Belanja langsung mendominasi komposisi belanja sektor pendidikan di Provinsi Papua, sedangkan di kabupaten/kota porsi belanja tidak langsung yang dominan. Sepanjang tahun 2007-2011 proporsi belanja langsung dalam komposisi belanja sektor pendidikan Provinsi Papua mencapai $86,08 \%$ per tahun atau senilai Rp. 174,61 milyar per tahun. Sedangkan untuk kabupaten/kota porsi belanja tidak langsungnya yang paling besar mencapai 52,85\% per tahun atau Rp. 1.107,20 milyar per tahun. Berdasarkan kecenderungan seperti ini dapat diindikasikan bahwa pembangunan sektor pendidikan di tingkat provinsi lebih 
mengarah pada pelayanan masyarakat secara langsung, sedangkan untuk sebagian besar kabupaten/kota cenderung pada aparaturnya, dalam hal ini lebih banyak untuk pegawai dinas dan guru.

\section{Gambar 7}

Proporsi Belanja Langsung dan Belanja Tidak Langsung Terhadap Total Belanja Sektor Pendidikan Menurut Kabupaten/Kota Di Papua Tahun 2012-2014 (dalam \%)

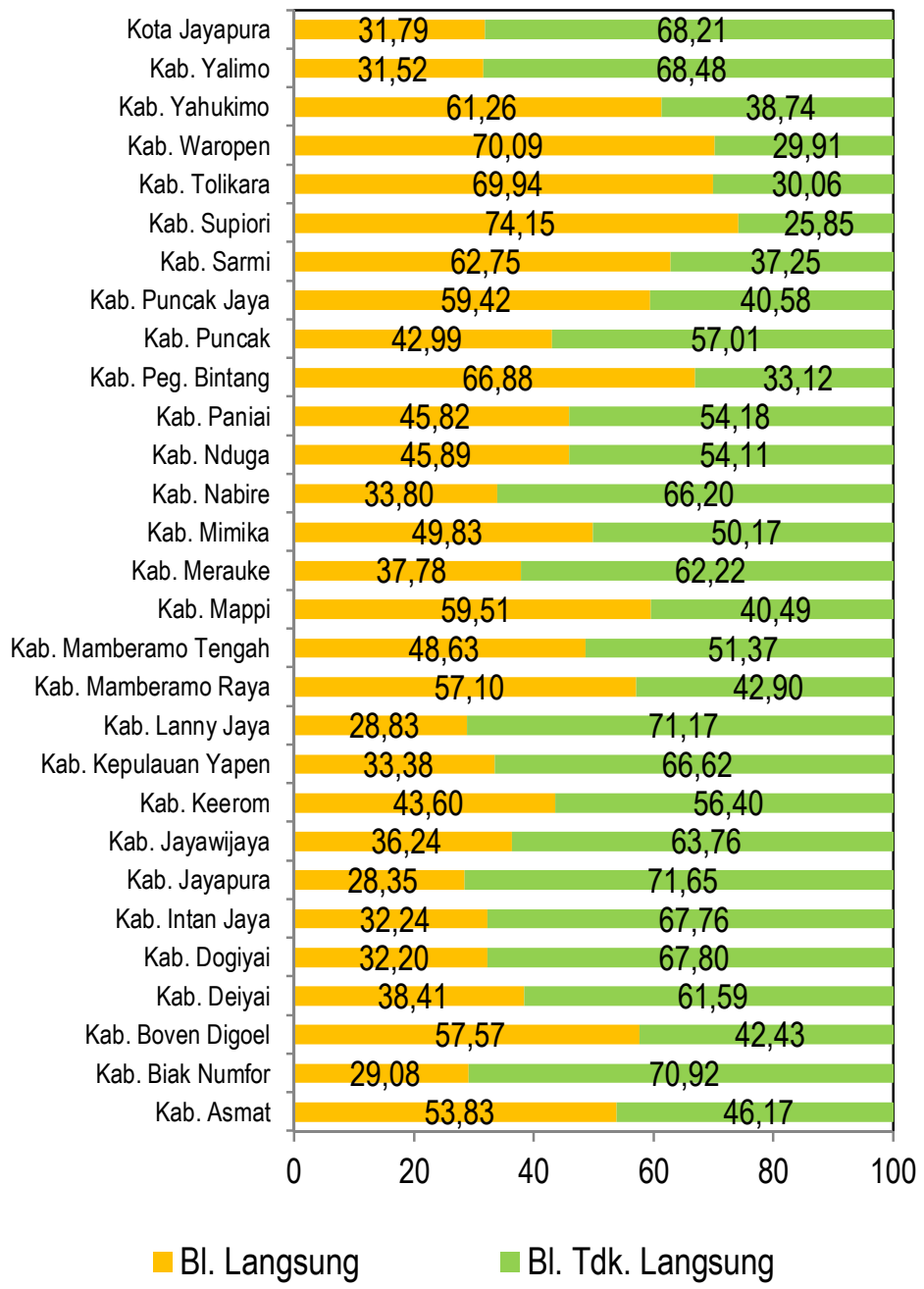

Sumber data : DJPK dan APBD Papua, 2012 (data di olah)

Daerah kabupaten/kota di Papua yang mengalokasikan belanja sektor pendidikannya lebih besar pada belanja langsung jumlahnya sedikit, kebanyakan setiap daerah mengalokasikannya pada belanja tidak 
langsung. Beberapa daerah yang lebih besar alokasinya pada belanja langsung hanya Kabupaten Supiori, Waropen, Mappi, Boven Digul, Mamberamo Raya, Tolikara, Pegunungan Bintang, Yahukimo, Puncak Jaya, dan Sarmi. Rata-rata alokasi belanja langsung pada daerah-daerah tersebut lebih dari 50\% per tahun. Paling tinggi adalah Kabupaten Supiori sekitar $74,15 \%$ per tahun. Beberapa daerah yang terindikasi paling besar belanja sektor pendidikannya di Papua, ternyata lebih banyak mengalokasikannya pada belanja tidak langsung. Seperti Kabupaten Merauke, Nabire, Biak Numfor dan Mimika, rata-rata alokasi belanja tak langsung sekitar $50 \%$ sampai dengan $70 \%$ per tahun.

\section{Analisis Efektifitas Dan Efisiensi Pengelolaan Keuangan Daerah Sektor Pendidikan}

Pengelolaan belanja sektor pendidikan di Provinsi Papua belum efektif dilaksanakan secara optimal untuk mencapai seluruh sasaran pembangunan pendidikan. Hal ini dapat dilihat dari hasil penggunaan belanja pada setiap kabupaten/kota di Papua yang tidak banyak terkait erat (berkorelasi signifikan) dengan beberapa indikator pencapaian (output/outcome) di bidang pendidikan. Sebagai misal, daerah-daerah kabupaten/kota yang memiliki belanja sektor pendidikan yang besar di Papua seperti Mimika, Asmat, Mappi, Lanny Jaya, Yahukimo, Paniai ternyata mempunyai rasio guru dengan murid yang tinggi melebihi standar SPN. Sementara beberapa daerah kabupaten yang memiliki belanja sektor pendidikan tergolong rendah di Papua seperti Pegunungan Bintang, Keerom, dan Puncak Jaya, semuanya mempunyai rasio guru dengan murid yang sangat ideal. Semua ini pada akhirnya membuat angka korelasi antara belanja pendidikan dengan rasio guru murid, sangat lemah dan tidak signifikan pada tingkat kepercayaan 90\%. Dimana besaran korelasi antara belanja pendidikan dan rasio guru murid hanya 0.0451 . Begitu juga dengan tingkat kelulusan UAN, penggunaan belanja oleh setiap pemerintah kabupaten/kota di Papua sepertinya tidak ada 
korelasi yang signifikan. Seluruh daerah kabupaten/kota di Papua mempunyai tingkat kelulusan UAN SD yang tinggi dengan rata-rata $98 \%$, baik itu yang memiliki belanja pendidikan besar maupun rendah. Termasuk pada APS usia pendidikan 7-12 tahun, penggunaan belanja oleh pemerintah kabupaten/kota di Papua belum efektif dapat meningkatkannya. Adapun besarnya korelasi antara belanja pendidikan dengan Kelulusan UAN dan APS masing-masing sebesar -0,0070 dan 0,0615 .

Tabel 2

Matriks Korelasi Input, Output dan Outcome Pembangunan Pendidikan Di Provinsi Papua

\begin{tabular}{|c|c|c|c|c|c|c|c|}
\hline \multirow{2}{*}{\multicolumn{2}{|c|}{ INPUT / OUTPUT }} & \multicolumn{6}{|c|}{ OUTPUT / OUTCOME } \\
\hline & & \multirow{2}{*}{$\begin{array}{c}\begin{array}{c}\text { Rasio } \\
\text { Guru } \\
\text { Murid SD }\end{array} \\
-0.0451\end{array}$} & \multirow{2}{*}{$\begin{array}{c}\begin{array}{c}\text { Angka } \\
\text { Buta } \\
\text { Aksara } \\
\text { (ABA) }\end{array} \\
-0.5176^{* *}\end{array}$} & \multirow{2}{*}{$\begin{array}{c}\text { Lulus } \\
\text { UAN SD } \\
-0.0070\end{array}$} & \multirow{2}{*}{$\begin{array}{c}\text { APS } \\
7-12 \\
0.0615\end{array}$} & \multirow{2}{*}{$\begin{array}{c}\text { Rata }{ }^{2} \text { Lama } \\
\text { Sekolah }\end{array}$} & \multirow{2}{*}{$\begin{array}{c}\text { APM } \\
0.3900^{* *}\end{array}$} \\
\hline Total & Correlation & & & & & & \\
\hline Pendkn & Sig. & 0.8164 & $0.0040^{* *}$ & 0.9714 & 0.7515 & $0.0001^{\star *}$ & $0.0365^{* *}$ \\
\hline \multirow{2}{*}{$\begin{array}{l}\text { Rasio } \\
\text { Guru } \\
\text { Murid }\end{array}$} & Correlation & $x$ & 0.1524 & 0.0206 & 0.0198 & -0.2131 & 0.0210 \\
\hline & Sig. & $x$ & 0.4300 & 0.9156 & 0.9188 & 0.2671 & 0.9137 \\
\hline
\end{tabular}

Sumber : data diolah (2015)

** signifikan pada tingkat kepercayaan $95 \%$

Besar kecilnya rasio guru dengan murid tidak efektif menyebabkan tingkat kelulusan UAN, APS, APM dan Rata-rata Lama sekolah semakin tinggi. Daerah-daerah kabupaten/kota di Papua yang mempunyai rasio guru dan murid yang sangat tidak ideal karena rasionya bisa di atas 50 murid per guru hingga 200 murid per guru misalnya Kabupaten Nabire, Yahukimo, Intan Jaya dan Supiori ternyata memiliki tingkat kelulusan UAN SD yang lebih tinggi, bahkan ada yang $100 \%$, dibandingkan dengan daerah-daerah kabupaten/kota yang mempunyai rasio guru dengan murid sangat ideal seperti Kabupaten Asmat, Puncak Jaya, Biak Numfor dan Mappi. Demikian juga untuk indikator APS, APM 
maupun Rata-rata Lama Sekolah, tidak efektif langsung semakin tinggi ketika guru ditambah. Ini berarti penambahan guru yang dapat memperbaiki rasio guru dengan murid dianggap tidak berkorelasi signifikan terhadap outcome pada sektor pendidikan. Semua ini tercermin pada serangkaian angka korelasi antara rasio guru murid dengan variabel-variabel pendidikan lainnya yang sangat lemah berkisar diantara 0.0200 sampai dengan 0,1524 , serta nonsignifikan pada tingkat kepercayaan $90 \%$.

Tata kelola belanja daerah di sektor pendidikan terlihat lebih efektif meningkatkan penuntasan buta huruf, Rata-rata Lama Sekolah, dan APM penduduk. Kondisi ini dapat dibuktikan dengan mengamati pola penyebaran besarnya belanja pendidikan pada setiap kabupaten/kota di Provinsi Papua yang kemudian dikaitkan dengan besaran ABA, Rata-rata Lama Sekolah dan APM. Dimana semakin tinggi total belanja pendidikan daerah, maka semakin kecil persentase $A B A$, semakin tinggi Rata-rata Lama Sekolah dan semakin besar APM. Sebaliknya pada daerah-daerah dimana total belanja pendidikannya kecil memiliki persentase ABA yang tinggi, Rata-rata Lama Sekolah yang rendah, dan APM yang kecil. Secara statistik fenomena tersebut terlihat pada angka korelasi antara belanja pendidikan dengan ABA sebesar $-0,5178$ yang sangat signifikan pada tingkat kepercayaan 95\%. Ini berarti besaran koefisien determinasinya adalah 0.2679 yang menunjukan bahwa variasi perubahan ABA (naik dan turun) sebesar $26,79 \%$ dideterminasi oleh variasi perubahan belanja pendidikan, dan sisanya $73,11 \%$ disebabkan oleh faktor-faktor lainnya. Adapun korelasi antara belanja pendidikan dengan Rata-Rata Lama Sekolah dan APM masing-masing sebesar 0,6701 dan 0,3900, dengan angka koefisien determinasinya masing-masing sebesar 0.4490 dan 0.1521 .

Berdasarkan seluruh besaran angka korelasi dan determinasi di atas, dapat digeneralisasikan bahwa belanja pendidikan yang dikeluarkan oleh pemerintah daerah di Papua tidak semua efektif untuk mencapai 
sasaran-sasaran pembangunan pendidikan. Dalam hal ini pengelolaan belanja sektor pendidikan di kabupaten/kota Provinsi Papua terlihat lebih efektif terhadap penurunan ABA, peningkatan Rata-Rata Lama Sekolah dan APM. Namun tidak efektif untuk meningkatkan rasio guru terhadap murid, Kelulusan UAN, dan APS.

Nilai efisiensi teknis pengelolaan keuangan daerah di sektor pendidikan di Provinsi Papua akan dihitung berdasarkan variabel input belanja untuk urusan pendidikan pada masing-masing pemerintah kabupaten/kota, dengan variabel output rasio sekolah terhadap murid dan rasio guru terhadap murid. Input belanja diukur menggunakan skala rasio dalam bentuk nilai belanja, sedangkan angka rasio untuk masing-masing variabel output keduanya merupakan skala perbandingan antara jumlah murid dengan sekolah, dan jumlah murid dengan guru. Sehingga dapat dikatakan output yang digunakan dalam menilai efisiensi teknis biaya ini adalah intermediate output.

Perbandingan antara input dan output dari belanja pendidikan hanya sebatas pada pemerintah kabupaten/kota yang berada di wilayah Papua. Hal ini merupakan salah satu keterbatasan yang cukup menonjol dalam studi kali ini, oleh karena tidak memandang keluar wilayah. Sedangkan asumsi yang digunakan adalah bahwa besarnya input anggaran belanja pendidikan yang dikeluarkan pemerintah kabupaten/kota mampu menghasilkan jumlah ouput fasilitas dan layanan pendidikan dengan besaran yang tidak sama. Dengan kata lain perhitungan efisiensi teknis biaya ini menggunakan asumsi Variabel Return to Scale (VRTS) dan model orientasi output (output oriented) serta cateris paribus. Hasil perhitungan nilai efisiensi teknis biaya pendidikan pemerintah kabupaten/kota di Provinsi Papua dikeluarkan dengan menggunakan program MDeap version 0.3.2 untuk tahun 2012, 2013 dan 2014, yang secara berurutan dapat dijelaskan sebagai berikut. 
Tabel 3

Nilai Efisiensi Teknis Belanja Pendidikan Berdasarkan Pemerintah Kabupaten/Kota Di Provinsi Papua Tahun 2012-2014

\begin{tabular}{|l|l|l|l|l|}
\hline \multicolumn{1}{|c|}{ Kabupaten/Kota } & 2012 & 2013 & 2014 & Rata-Rata \\
\hline Merauke & 0.570 & 0.609 & 0.682 & 0.6203 \\
\hline Jayawijaya & 0.562 & 0.578 & 0.697 & 0.6123 \\
\hline Jayapura & 0.544 & 0.572 & 0.715 & 0.6103 \\
\hline Nabire & 0.646 & 0.976 & 0.745 & 0.7890 \\
\hline Yapen Waropen & 0.665 & 0.971 & 0.761 & 0.7990 \\
\hline Biak Numfor & 0.693 & 0.870 & 0.765 & 0.7760 \\
\hline Paniai & 0.514 & 0.793 & 1.000 & 0.7690 \\
\hline Puncak Jaya & 0.502 & 0.786 & 0.960 & 0.7493 \\
\hline Mimika & 0.500 & 0.839 & 1.000 & 0.7797 \\
\hline Boven Digoel & 0.974 & 0.638 & 0.668 & 0.7600 \\
\hline Mappi & 0.896 & 0.618 & 0.737 & 0.7503 \\
\hline Asmat & 1.000 & 0.673 & 0.792 & 0.8217 \\
\hline Yahukimo & 0.833 & 1.000 & 1.000 & 0.9443 \\
\hline Pegunungan Bintang & 0.752 & 1.000 & 0.545 & 0.7657 \\
\hline Tolikara & 0.809 & 1.000 & 0.498 & 0.7690 \\
\hline Sarmi & 1.000 & 0.598 & 0.498 & 0.6987 \\
\hline Keerom & 0.853 & 0.621 & 1.000 & 0.8247 \\
\hline Waropen & 1.000 & 0.631 & 0.515 & 0.7153 \\
\hline Supiori & 0.753 & 0.942 & 1.000 & 0.8983 \\
\hline Mamberamo Raya & 0.818 & 1.000 & 0.791 & 0.8697 \\
\hline Nduga & 1.000 & 1.000 & 0.803 & 0.9343 \\
\hline Lanny Jaya & 0.554 & 0.705 & 0.465 & 0.5747 \\
\hline Mamberamo Tengah & 0.519 & 0.996 & 0.736 & 0.7503 \\
\hline Yalimo & 0.531 & 0.700 & 0.513 & 0.5813 \\
\hline Puncak & 1.000 & 1.000 & 0.841 & 0.9470 \\
\hline Dogiyai & 0.990 & 0.897 & 0.877 & 0.9213 \\
\hline Deiyai & 1.000 & 1.000 & 0.970 & 0.9900 \\
\hline Intan Jaya & 0.599 & 0.714 & 1.000 & 0.7710 \\
\hline Kota Jayapura & 0.574 & 0.645 & 1.000 & 0.7397 \\
\hline Mean & 0.744 & 0.800 & 0.786 & 0.7767 \\
\hline Sur $\mid$ & & & & \\
\hline
\end{tabular}

Sumber : data diolah (2015) 
Pada tahun 2012 terdapat 6 (enam) pemerintah kabupaten yang diindikasikan telah menggunakan belanja sektor pendidikannya secara efisien. Ke-6 kabupaten tersebut adalah Asmat, Sarmi, Waropen, Nduga, Puncak dan Deyiai, oleh karena semuanya mempunyai skor efisiensi sebesar 1 atau 100\%. Daerah-daerah ini dapat dikatakan mampu mengelola belanja di sektor pendidikan yang lebih efisien dalam upaya mencapai output rasio sekolah dan guru terhadap murid yang lebih ideal dibandingkan daerah-daerah lainnya. Dengan kata lain secara normatif setiap tambahan input berupa belanja pendidikan pada setiap kabupaten tersebut mampu menghasilkan output yang lebih baik dibandingkan daerah-daerah lainnya. Adapun untuk yang tidak efisien mengelola belanja pendidikannya teridentifikasi sebanyak 23 pemerintah kabupaten/kota.

Beberapa daerah yang maju di Provinsi Papua ternyata ada yang tergolong tidak efisien dan di bawah rata-rata efisiensinya dalam mengelola belanja pendidikan. Teridentifikasi pada pemerintah Kota Jayapura, Kabupaten Merauke, Jayapura, Nabire, Biak Numfor dan Mimika termasuk daerah-daerah yang tidak efisien mengelola belanja pendidikannya di tahun 2012 oleh karena mempunyai skor efisiensi di bawah rata-rata berkisar antara 0,50 (50\%) sampai 0,6930 (69,30\%). Dimana yang terendah adalah Kabupaten Mimika. Hal ini mengindikasikan bahwa di daerah-daerah tersebut masih kurang optimal dalam mengelola belanja sektor pendidikan, yang tidak diikuti dengan penyediaan fasilitas dan sarana pendidikan dasar bagi masyarakatnya yang lebih baik. Dimana salah satu permasalahan yang sering ditemui pada daerah-daerah yang terbilang maju di Papua tersebut adalah jumlah sekolah yang tersedia tampak masih belum memadai dibandingkan jumlah murid dalam rasio yang ideal bila dibandingkan dengan daerah lainnya. Meskipun biaya pendidikan yang dikeluarkan lebih tinggi dibandingkan daerah-daerah yang tergolong efisien (seperti Deyiai, Sarmi, dan Puncak) akan tetapi output rasio sekolah terhadap 
murid yang dihasilkan terlihat kurang ideal. Misalkan di Kota Jayapura rasionya mencapai 390 murid per sekolah, padahal belanja pendidikan yang dikeluarkan sebesar Rp. 277.027,19 juta. Sedangkan Kabupaten Deyiai dengan belanja pendidikan yang lebih rendah yakni sebesar Rp. $66.152,44$ juta mampu menciptakan rasio sekolah terhadap murid yang lebih ideal di bandingkan Kota Jayapura yaitu 180 murid per sekolah. Sehingga Kabupaten Deyiai lebih terpilih sebagai benchmark efisiensi di Provinsi Papua dibandingkan Kota Jayapura.

Sampai dengan tahun 2013 hanya Kabupaten Nduga, Puncak dan Deyiai yang mampu mempertahankan kinerja pengelolaan belanja di sektor pendidikan. Sedangkan Kabupaten Asmat, Sarmi dan Waropen menjadi tidak efisien di tahun 2013 ini, karena mempunyai skor efisiensi di bawah 1 atau 100\%. Terlihat juga ada 6 daerah kabupaten yang mampu meningkatkan efisiensi kinerja belanjanya di sektor pendidikan yaitu Kabupaten Paniai, Mimika, Yahukimo, Pegunungan Bintang, Tolikara, dan Mamberamo Raya, oleh karena daerah-daerah tersebut di tahun 2013 mampu memperbaiki rasio sekolah dan guru terhadap murid yang lebih ideal dengan tambahan belanja yang lebih sedikit dibandingkan daerah-daerah lainnya. Namun untuk Kota Jayapura, Kabupaten Merauke, Nabire, Jayapura dan Biak Numfor terindikasi di tahun 2013 masih dalam kondisi yang tidak efisien. Sepertinya belum ada perbaikan output belanja yang lebih signifikan pada daerah-daerah tersebut di tahun 2013. Termasuk beberapa daerah lainnya di pegunungan dan dataran sulit akses seperti Jayawijaya, Puncak Jaya, Dogiyai, Paniai, Mappi, Boven Digul, dan sebagainya.

Di tahun 2014 jumlah kabupaten/kota yang terindikasi efisien dalam mengelola belanja di sektor pendidikan lebih banyak dibandingkan tahun sebelumnya. Dalam hal ini terdapat 7 kabupaten yang dapat dinyatakan efisien mengelola belanja pendidikannya oleh karena memiliki skor sebesar 1 atau 100\%, yaitu Kabupaten Paniai, Mimika, Yahukimo, Keerom, Supiori, Intan Jaya dan Kota Jayapura. Terlihat juga sebagian 
besar pada daerah tersebut merupakan daerah-daerah yang mampu secara maksimal mengupayakan perbaikan kinerja efisiensi teknis belanja sektor pendidikan, misalkan Kabupaten Mimika, Keerom, Supiori, dan Kota Jayapura, yang mana untuk 2 tahun sebelumnya selalu dinyatakan tidak efisien.

Hingga tahun 2014 ada 15 kabupaten yang sama sekali belum mampu memperbaiki efisiensi teknis belanja di sektor pendidikan. Ke-15 kabupaten yang dimaksud adalah Kabupaten Merauke, Jayawijaya, Jayapura, Nabire, Yapen Waropen, Biak Numfor, Puncak Jaya, Boven Digoel, Mappi, Asmat, Waropen, Lanny Jaya, Mamberamo Tengah, Yalimo dan Dogiyai. Selain rasio sekolah terhadap murid yang belum ideal, juga di beberapa daerah tersebut mempunyai rasio guru terhadap murid yang kurang ideal meskipun belanja pendidikan terus menerus ditambah setiap tahunnya.

Jika diamati dari tahun 2012 sampai dengan 2014 secara rata-rata sebenarnya tidak ada satu pun daerah kabupaten/kota yang dapat dikatakan efisien dalam mengelola belanja sektor pendidikan. Meskipun demikian terlihat bahwa ada beberapa daerah yang mempunyai skor efisiensi rata-rata mendekati $100 \%$, yang semuanya berada di daerah pegunungan yakni Kabupaten Yahukimo, Nduga, Puncak, Dogiyai, dan Deiyai. Sehingga dari hasil kajian efisiensi teknis belanja sepanjang tahun 2012-2014 dapat digeneralisasikan bahwa Kabupaten Yahukimo, Nduga, Puncak, Dogiyai, dan Deiyai merupakan daerah-daerah yang paling tinggi efisiensinya, serta dapat menjadi benchmark untuk pengelolaan belanja di sektor pendidikan yang lebih baik.

Berbeda dengan efisiensi teknis belanja, untuk efisiensi teknis sistem pendidikan diukur dengan memasukan input berupa intermediate output dengan keluarannya berupa outcome di sektor pendidikan.Dalam hal ini input yang digunakan adalah rasio sekolah dan guru terhadap murid (intermediate output), sedangkan outcome terdiri atas Angka Partisipasi Murni (APM) dan Rata-Rata Lama Sekolah (RLS), yang mana 
keduanya mewakili kemampuan akses pendidikan pada penduduk di masing-masing kabupaten/kota.

Tabel 4

Nilai Efisiensi Teknis Sistem Di Sektor Pendidikan Berdasarkan Pemerintah Kabupaten/Kota Di Provinsi Papua Tahun 2012-2014

\begin{tabular}{|l|l|l|l|l|}
\hline \multicolumn{1}{|c|}{ Kabupaten/Kota } & 2012 & 2013 & 2014 & Rata-Rata \\
\hline Merauke & 0.746 & 0.994 & 0.939 & 0.8930 \\
\hline Jayawijaya & 0.761 & 0.998 & 0.945 & 0.9013 \\
\hline Jayapura & 0.758 & 1.000 & 0.952 & 0.9033 \\
\hline Nabire & 0.713 & 0.703 & 0.987 & 0.8010 \\
\hline Yapen Waropen & 0.699 & 0.707 & 0.988 & 0.7980 \\
\hline Biak Numfor & 0.704 & 0.713 & 0.988 & 0.8017 \\
\hline Paniai & 1.000 & 0.711 & 0.708 & 0.8063 \\
\hline Puncak Jaya & 0.997 & 0.716 & 0.713 & 0.8087 \\
\hline Mimika & 1.000 & 0.726 & 0.719 & 0.8150 \\
\hline Boven Digoel & 0.688 & 1.000 & 0.742 & 0.8100 \\
\hline Mappi & 0.692 & 0.982 & 0.731 & 0.8017 \\
\hline Asmat & 0.698 & 0.970 & 0.720 & 0.7960 \\
\hline Yahukimo & 0.662 & 0.690 & 0.966 & 0.7727 \\
\hline Pegunungan Bintang & 0.799 & 0.695 & 0.971 & 0.8217 \\
\hline Tolikara & 1.000 & 0.701 & 0.979 & 0.8933 \\
\hline Sarmi & 0.813 & 1.000 & 1.000 & 0.9377 \\
\hline Keerom & 0.671 & 1.000 & 1.000 & 0.8903 \\
\hline Waropen & 0.669 & 1.000 & 1.000 & 0.8897 \\
\hline Supiori & 0.763 & 0.978 & 0.752 & 0.8310 \\
\hline Mamberamo Raya & 0.767 & 0.987 & 0.758 & 0.8373 \\
\hline Nduga & 0.775 & 0.992 & 0.761 & 0.8427 \\
\hline Lanny Jaya & 1.000 & 0.945 & 1.000 & 0.9817 \\
\hline Mamberamo Tengah & 1.000 & 0.956 & 1.000 & 0.9853 \\
\hline Yalimo & 1.000 & 0.975 & 0.996 & 0.9903 \\
\hline
\end{tabular}




\begin{tabular}{|l|l|l|l|l|}
\hline \multicolumn{1}{|c|}{ Kabupaten/Kota } & 2012 & 2013 & 2014 & Rata-Rata \\
\hline Puncak & 1.000 & 0.732 & 0.717 & 0.8163 \\
\hline Dogiyai & 1.000 & 0.726 & 0.727 & 0.8177 \\
\hline Deiyai & 1.000 & 0.714 & 0.733 & 0.8157 \\
\hline Intan Jaya & 1.000 & 0.873 & 0.702 & 0.8583 \\
\hline Kota Jayapura & 0.991 & 0.883 & 0.707 & 0.8603 \\
\hline Mean & 0.845 & 0.866 & 0.854 & 0.8550 \\
\hline
\end{tabular}

Sumber : data diolah (2015)

Meskipun beberapa daerah teridentifikasi tidak efisien dalam tata kelola belanjanya, namun untuk mengelola intermediate output menjadi outcome ada yang terlihat cukup efisien. Misalkan Kabupaten Jayawijaya, Jayapura, Sarmi, Lanny Jaya, Mamberamo Tengah dan Yalimo semuanya mampu mencapai efisiensi teknis sistem yang lebih tinggi dibandingkan daerah kabupaten/kota lainnya. Walaupun secara rata-rata tidak mencapai $100 \%$, akan tetapi skor efisiensi teknis sistem yang dihasilkan di atas $90 \%$, yang tertinggi adalah Kabupaten Yalmo mencapai 99,03\%. Ini berarti kabupaten tersebut mampu menghasilkan Angka Partisipasi Murni dan Rata-Rata Lama Sekolah yang lebih sepadan dengan input yang digunakan yang diwujudkan pada rasio sekolah dan guru terhadap murid.

Serupa dengan efisiensi teknis biaya, daerah kabupaten/kota yang pencapaian skor efisiensi teknis sistemnya tidak mencapai angka 1 atau $100 \%$, maka secara empiris daerah-daerah tersebut tergolong ke dalam daerah yang tidak efisien dalam teknis sistem. Misalkan Kabupaten Merauke, Nabire, Yapen Waropen, Biak Numfor, Paniai, Yahukimo dan Deiyai mempunyai skor efisiensi teknis sistem di bawah rata-rata 0,8550 atau $85,50 \%$. Semakin kecil pencapaian skor efisiensinya maka semakin tidak efisien daerah tersebut. Dengan kata lain kebijakan menambah jumlah fasilitas dan layanan pendidikan pada daerah-daerah yang inefisien jika tidak diikuti dengan adanya perbaikan 
sistem pendidikan justru akan berdampak negatif pada pencapaian kualitas pendidikan masyarakat. Perbaikan sistem pendidikan ini dapat dilakukan dengan cara menambah guru yang sudah ada untuk menjangkau lebih banyak penduduk yang membutuhkan layanan pendidikan, selain itu diperlukan koordinasi lintas kabupaten/kota di Provinsi Papua yang dimotori oleh pemerintah provinsi terkait dengan pemerataan guru terutama dari Kota Jayapura ke kabupaten lain yang masih kekurangan tenaga guru di Provinsi Papua.

Merujuk kepada hasil pengukuran efisiensi tata kelola belanja (teknis biaya) dan outcome (teknis sistem) menggunakan DEA tervisualisasi sebagian besar di Provinsi Papua belum maksimal melakukan pengelolaan keuangan daerah di sektor pendidikan secara efisien. Dalam hal ini ditemukan beberapa fonemena sebagai berikut :

a. Tidak ada satupun daerah yang teridentifikasi mampu mewujudkan efisiensi teknis belanja dan teknis sistem bersamaan. Sehingga tidak ada daerah yang dapat dinyatakan sangat ideal, bersinergi dan terintegrasi dalam mengelola keuangan daerah di sektor pendidikan. Namun secara parsial dapat disebutkan bahwa untuk efisiensi teknis belanja yang dapat dijadikan benchmark adalah Kabupaten Deiyai, Nduga dan Puncak, oleh karena mempunyai skor efisiensi teknis belanja yang mendekati angka 1 atau 100\%. Sedangkan untuk efisiensi teknis sistem yang dapat menjadi benchmark adalah Kabupaten Yalimo, Mamberamo Tengah dan Lanny Jaya.

b. Kabupaten/kota yang teridentifikasi efisien dalam tata kelola belanja di tahun tertentu belum pasti akan efisien juga dalam teknis sistem, begitu sebaliknya. Misalkan Kabupaten Paniai, Mimika, Yahukimo dan Kota Jayapura di tahun 2014 dapat mencapai efisiensi teknis belanja (rasio sebesar 100\%), akan tetapi untuk teknis sistem tidak efisien. Sebaliknya untuk Kabupaten Sarmi, Waropen, Lanny Jaya dan Mamberamo Tengah semuanya mampu menghasilkan teknis sistem yang efisien (rasio 100\%), namun tidak berhasil menciptakan 
teknis belanja yang efisien (rasio di bawah 100\%). Berdasarkan hasil tersebut maka pemerintah provinsi dapat mengevaluasi kebijakan anggaran belanja sektor pendidikan yang diambil terkait pencapaian efisiensi yang terjadi. Apabila pemerintah provinsi lebih berorientasi pada pencapaian efisiensi teknis belanja, maka kebijakan yang ditempuh pada tahun mendatang sudah tepat dan tidak perlu ada perubahan jumlah target baik input maupun output. Namun, jika dalam mengambil kebijakan anggaran belanja sektor pendidikan pemerintah provinsi lebih berorientasi pada pencapaian efisiensi teknis sistem maka langkah kebijakan yang dapat ditempuh adalah melakukan pemerataan sumber daya tenaga pendidik misalkan dengan melakukan redistribusi guru ke daerah-derah yang masih sangat kurang seperti Kabupaten Yahukimo, Tolikara, Nduga, Mamberamo Tengah, Yalimo, Dogiyai, Deiyai dan Intan Jaya yang pada umumnya mempunyai rasio guru terhadap murid di atas 40 hingga 135 orang.

c. Dengan kondisi teknis efisiensi belanja dan sistem seperti sekarang ini, tampaknya seluruh daerah kabupaten/kota di Provinsi Papua sedang mengalami permasalahan yang sangat serius dalam mengelola keuangan daerah di sektor pendidikan, mulai dari perencanaan, penganggaran, pelaporan, pengawasan, hingga monitoring dan evaluasi. Dimana hal ini ditunjukan secara agregat dengan masih belum optimalnya tata kelola belanja dalam mewujudkan output/outcome yang ditargetkan.

\section{KESIMPULAN DAN SARAN}

\section{Kesimpulan}

a. Sebagian besar daerah yang terletak di pegunungan (Kawasan La Pago dan Me Pago) pada umumnya belum dapat menuntaskan program pendidikan dasar sembilan tahun. Selain itu Persentase 
penduduk yang buta huruf di daerah-daerah pegunungan terlihat lebih tinggi dibandingkan penduduk di pesisir dan dataran rendah. Selanjutnya apabila diperhatikan menurut kewilayahan, jumlah penduduk usia sekolah yang mendapat kesempatan untuk bersekolah pada masing-masing kabupaten/kota di Papua cukup tinggi, namun terlihat timpang. Di sebagian besar kabupaten yang berada di daerah pedalaman dan pegunungan memiliki rasio guru terhadap murid di tingkat SD yang melebihi batas maksimal Standar Pendidikan Nasional.

b. Anggaran belanja untuk pembangunan sektor pendidikan di Papua terlihat cukup besar, akan tetapiu cenderung mengalami pertumbuhan yang agak lambat. Jika dilihat menurut kabupaten/kota, terdapat tiga daerah yang memiliki belanja sektor pendidikan paling besar di Papua yaitu Kota Jayapura, Kabupaten Mimika dan Kabupaten Merauke. Adapun untuk daerah-daerah lainnya yang sebagian besar terletak di daerah pegunungan dan dataran sulit akses mempunyai belanja sektor pendidikan yang rendah

c. Porsi belanja sektor pendidikan dalam komposisi anggaran pemerintah daerah di Papua belum memenuhi amanat dari undang-undang pendidikan maupun Otsus. Namun, meskipun secara keseluruhan terlihat rendah, akan tetapi jika diamati pada masing-masing kabupaten ada sebagian daerah yang telah memenuhi amanat undang-undang misalkan Kota Jayapura dan Kabupaten Merauke.

d. Belanja langsung mendominasi komposisi belanja sektor pendidikan di Provinsi Papua, sedangkan di kabupaten/kota porsi belanja tidak langsung yang dominan.

e. Jika diamati dari tahun 2012 sampai dengan 2014 secara rata-rata tidak ada satu pun daerah kabupaten/kota yang dapat dikatakan efisien dalam mengelola belanja sektor pendidikan. Tetapi untuk 
tahun-tahun tertentu secara terpisah ada beberapa daerah yang teridentifikasi dapat efisien dalam melaksanakan tata kelola belanja di sektor pendidikan, misalkan Kabupaten Paniai, Mimika, Yahukimo, Keerom, Supiori, Intan Jaya dan Kota Jayapura. Fenomena ini menggambarkan bahwa pengelolaan keuangan daerah sektor pendidikan di Provinsi Papua berlangsung sangat tidak konsisten dan tidak terintegrasi antarwaktu.

f. Meskipun beberapa daerah teridentifikasi tidak efisien dalam tata kelola belanjanya, namun untuk mengelola intermediate output menjadi outcome ada yang terlihat cukup efisien, seperti Kabupaten Jayawijaya, Jayapura, Sarmi, Lanny Jaya, Mamberamo Tengah dan Yalimo semuanya berhasil mencapai efisiensi teknis sistem yang lebih tinggi dibandingkan daerah kabupaten/kota lainnya, walaupun itu sebenarnya belum mencapai rasio efisiensi $100 \%$.

g. Merujuk kepada hasil pengukuran efisiensi tata kelola belanja (teknis biaya) dan outcome (teknis sistem) menggunakan DEA tervisualisasi sebagian besar di Provinsi Papua belum maksimal melakukan pengelolaan keuangan daerah di sektor pendidikan secara efisien

\section{Saran}

a. Hendaknya pemerintah di masing-masing kabupaten/kota yang belum mencapai efisiensi teknis biaya melakukan monitoring dan evaluasi, serta peningkatan efisiensi terhadap pengeluaran pemerintah daerah khususnya pada anggaran sektor pendidikan. Peningkatan efisiensi dapat dilakukan dengan cara optimalisasi pengelolaan anggaran belanja pendidikan yang dikeluarkan pemerintah. Langkah ini dilakukan dengan meningkatkan fasilitas dan layanan pendidikan dasar masyarakat di daerahnya masing-masing 
sesuai dengan kebutuhan yang telah ditargetkan dalam RPJMD Kabupaten/Kota dengan memperhatikan RPJMD Provinsi Papua.

b. Kabupaten/kota yang tidak efisien secara sistem adalah daerah yang penggunaan input berupa fasilitas dan layanan pendidikan belum efisien penggunaannya. Terkait dengan hal tersebut, pemerintah kabupaten/kota dengan dikoordinasikan oleh pemerintah Provinsi Papua dapat melakukan redistribusi guru pada daerah-daerah yang masih kekurangan.

c. Penggunaan DEA sebagai alat analisis memiliki beberapa kelemahan, salah satunya adalah metode DEA berasumsi bahwa setiap unit input atau output identik dengan unit lain dalam tipe yang sama dan tidak mampu mengenali perbedaan tersebut. Untuk memenuhi asumsi tersebut, maka untuk studi lebih lanjut perlu menggunakan daerah-daerah yang memiliki rentang rasio sekolah dan guru terhadap murid yang relatif tidak jauh berbeda sebagai sampel penelitian. Selain itu penggunaan data rasio sekolah dan guru terhadap murid yang tidak membedakan jenjang pendidikan sebagai indikator biaya dalam penelitian ini memiliki kelemahan, karena diketahui bahwa kebutuhan pendanaan di tiap jenjang sekolah tidak mungkin sama, Sekolah menengah akan membutuhkan sarana laboratorium dan ruang praktikum mahal yang mungkin belum dibutuhkan di jenjang sekolah dasar. Selain itu asumsi bahwa biaya tersebut habis teralokasi untuk penggunaan pengeluaran dan tidak adanya pemisahan antara biaya tetap dan variabel, membuat komposisi biayanya tidak bisa terlihat.

\section{DAFTAR PUSTAKA}

Ahmad Syakir Kurnia. 2006. Model Pengukuran Kinerja dan Efisiensi Sektor Publik Metode Free Disposable Hull (FDH). Jurnal Ekonomi Pembangunan, Vol.11, No. 2, h. 1-20. 
BPS Papua. 2014. Indikator Pendidikan Provinsi Papua 2014. Badan Pusat Statistik Provinsi Papua, Jayapura. 2015. Papua Dalam Angka Tahun 2015. Badan Pusat Statistik Provinsi Papua, Jayapura.

Cooper William, Lawrence M. Seiford and Joe Zhu. Chapter 1 : Data Envelopment Analysis: History, Models and Interpretations [http://users.wpi.edu/ jzhu/dea/hbchapter1.pdf]

Esanov, Akram. Efficiency of Public Spending in Resources-Rich PostSoviet

Gupta, Sanjev, Keiko Honjo, and Marijn Verhoeven. 1997. The efficiency of Government Expenditure : Experiences From Africa. IMF workin Paper No. 153.

Haryadi, A. 2011. Analisis Efisiensi Teknis Bidang Pendidikan : Penerapan Data Envelopment Analysis. Tesis Program Magister Perencanaan Dan Kebijakan Publik Ekonomi Keuangan Negara Dan Daerah, FE UI, Jakarta.

Herera, S., and Pang, G. 2005. Efficiency of Public Spending in Developing Countries : An Efficiency Frontier Approach, World Bank Policy Research Working Paper 3645, Juni 2005.

Jafarov, Etibar and Anna Ilyina . 2008. Republic of Croatia: Selected Issues. IMF Country Report No. 08/159.

DJPK. 2015. APBD, Realisasi APBD, dan Neraca Pemerintah Daerah. http://www.djpk.kemenkeu.go.id

Lela, D.P. 2007. Efisiensi Pengeluaran Pemerintah Daerah di Propinsi Jawa Tengah. Jurnal Ekonomi Pembangunan Vol. 12 No.2, hal : 123-139.

Lewis, Blane D. 2007. Minimum Service Standard in Indonesian Primary School Education : Input, Output, Cost and Efficiency, Decentralization Support Facility. Jakarta.

Nazaruddin, Y. Y., et al. 2014. APK/APM PAUD, SD, SMP, SM dan PT Tahun 2013/2014. Bidang Pendayagunaan dan Pelayanan Data dan Statistik Pendidikan, Kementerian Pendidikan dan Kebudayaan RI, Jakarta.

Nugroho, R.P. 2003. Penerapan Data Envelopment Analysis (DEA) dalam Kasus Pemilihan Produk Inkjet Personal Printer. Usahawan No. 10 Th. XXXII, Jakarta.

Talluri, S. 2000. Data Envelopment Analysis: Models and Extensions. Decision Line 31(3): p. 8-11. 
Lampiran 1. Realisasi Total Belanja Dan Belanja Sektor Pendidikan Di Provinsi Papua Menurut Kabupaten/Kota Tahun 2012-2014 (Rp. Juta)

\begin{tabular}{|c|c|c|c|c|c|c|}
\hline \multirow[b]{2}{*}{ Daerah } & \multicolumn{2}{|c|}{2012} & \multicolumn{2}{|c|}{2013} & \multicolumn{2}{|c|}{2014} \\
\hline & $\begin{array}{c}\text { Total } \\
\text { Belanja }\end{array}$ & Pendidikan & $\begin{array}{c}\text { Total } \\
\text { Belanja }\end{array}$ & Pendidikan & Total Belanja & Pendidikan \\
\hline Kab. Biak Numfor & $578.353,90$ & $190.698,11$ & $732.864,10$ & $210.693,23$ & $812.237,90$ & $224.218,80$ \\
\hline Kab. Jayapura & $678.843,48$ & $171.467,30$ & $792.112,25$ & $191.323,87$ & $889.844,09$ & $228.940,12$ \\
\hline Kab. Jayawijaya & $686.862,64$ & $35.737,85$ & $988.273,14$ & $62.461,28$ & $810.715,00$ & $86.956,91$ \\
\hline Kab. Merauke & $1.295 .123,28$ & $277.546,62$ & $1.701 .648,09$ & $335.921,20$ & $1.846 .696,26$ & $333.835,23$ \\
\hline Kab. Mimika & $1.333 .818,09$ & $196.837,51$ & $1.361 .299,96$ & $215.682,85$ & $1.730 .000,00$ & $275.468,18$ \\
\hline Kab. Nabire & $743.661,59$ & $164.478,83$ & $703.756,15$ & $236.675,47$ & $889.349,79$ & $254.946,19$ \\
\hline Kab. Paniai & $552.687,20$ & $110.218,75$ & $697.203,65$ & $122.177,04$ & $747.960,89$ & $117.109,67$ \\
\hline Kab. Puncak Jaya & $588.416,46$ & $62.787,96$ & $764.648,75$ & $93.891,89$ & $997.674,19$ & $111.154,02$ \\
\hline Kab. Yahukimo & $650.012,79$ & $115.034,30$ & $822.338,22$ & $110.849,43$ & $900.916,12$ & $128.786,15$ \\
\hline Kota Jayapura & $795.587,22$ & $277.027,20$ & $888.045,58$ & $310.979,08$ & $1.057 .945,38$ & $336.776,67$ \\
\hline Kab. Mamberamo Raya & $634.384,41$ & $45.292,08$ & $815.651,12$ & $61.188,83$ & $997.015,95$ & $80.451,69$ \\
\hline Kab. Tolikara & $531.650,62$ & $82.138,20$ & $760.960,00$ & $78.550,94$ & $923.973,29$ & $115.216,53$ \\
\hline Kab. Keerom & $681.919,00$ & $68.084,54$ & $803.753,19$ & $136.639,59$ & $745.532,29$ & $131.317,72$ \\
\hline Kab. Pegunungan Bintang & $794.071,38$ & $94.730,12$ & $961.095,82$ & $104.302,08$ & $1.092 .152,37$ & $144.874,26$ \\
\hline Kab. Boven Digoel & $877.323,47$ & $77.677,02$ & $964.790,31$ & $95.603,92$ & $1.072 .639,46$ & $101.624,56$ \\
\hline Kab. Mappi & $741.595,41$ & $113.703,95$ & $691.849,57$ & $90.068,66$ & $1.007 .879,49$ & $191.564,88$ \\
\hline Kab. Asmat & $903.534,54$ & $126.766,73$ & $1.069 .124,01$ & $139.565,96$ & $1.130 .201,42$ & $159.871,90$ \\
\hline Kab. Waropen & $504.708,41$ & $66.501,69$ & $620.688,49$ & $80.563,49$ & $691.300,07$ & $81.907,00$ \\
\hline Kab. Sarmi & $527.868,71$ & $66.501,69$ & $687.188,56$ & $69.067,69$ & $906.009,94$ & $76.791,17$ \\
\hline Kab. Supiori & $531.962,22$ & $47.362,14$ & $599.149,18$ & $55.418,23$ & $717.818,97$ & $61.055,73$ \\
\hline Kab. Lanny Jaya & $629.120,46$ & $127.380,93$ & $772.362,15$ & $106.771,80$ & $912.510,41$ & $130.187,07$ \\
\hline Kab. Nduga & $642.475,37$ & $66.549,26$ & $700.891,20$ & $57.904,59$ & $732.096,18$ & $78.696,55$ \\
\hline Kab. Puncak & $977.043,45$ & $79.508,62$ & $1.234 .550,58$ & $132.999,41$ & $1.340 .520,75$ & $98.072,61$ \\
\hline Kab. Dogiyai & $439.562,01$ & $63.169,02$ & $561.310,25$ & $87.634,96$ & $757.944,40$ & $123.306,80$ \\
\hline Kab. Mamberamo Tengah & $582.541,45$ & $83.978,33$ & $745.650,72$ & $63.663,32$ & $885.442,01$ & $91.428,90$ \\
\hline Kab. Yalimo & $593.778,98$ & $75.936,39$ & $739.020,28$ & $79.457,56$ & $872.300,21$ & $94.996,96$ \\
\hline Kab. Kepulauan Yapen & $554.474,48$ & $143.208,33$ & $589.090,96$ & $157.109,87$ & $721.791,06$ & $195.733,94$ \\
\hline Kab. Intan Jaya & $629.487,34$ & $69.389,90$ & $776.890,78$ & $76.900,12$ & $911.005,44$ & $71.728,43$ \\
\hline Kab. Deiyai & $505.676,84$ & $66.152,44$ & $531.745,46$ & $80.625,11$ & $591.105,46$ & $87.512,62$ \\
\hline Prov. Papua & $7.239 .667,12$ & $129.205,55$ & $8.034 .735,97$ & $181.772,54$ & $11.205 .078,38$ & $88.724,34$ \\
\hline
\end{tabular}

Sumber : DJPK Kementerian Keuangan RI (2015) 
Lampiran 2. Rata-Rata Rasio Sekolah Dan Guru Terhadap Untuk Jenjang Pendidikan Dasar Sembilan Tahun Di Provinsi Papua Tahun 2012-2013 (orang)

\begin{tabular}{|l|c|c|c|c|c|c|}
\hline \multirow{2}{*}{ Kabupaten/Kota } & \multicolumn{2}{|c|}{2012} & \multicolumn{2}{c|}{2013} & \multicolumn{2}{c|}{2014} \\
\cline { 2 - 7 } & R-SM & R-GM & R-SM & R-GM & R-SM & R-GM \\
\hline Merauke & 181 & 20 & 186 & 22 & 192 & 21 \\
\hline Jayawijaya & 211 & 29 & 219 & 30 & 221 & 30 \\
\hline Jayapura & 164 & 18 & 172 & 20 & 176 & 21 \\
\hline Nabire & 196 & 22 & 203 & 22 & 208 & 22 \\
\hline YapenWaropen & 159 & 20 & 160 & 19 & 163 & 18 \\
\hline BiakNumfor & 157 & 18 & 160 & 22 & 161 & 23 \\
\hline Paniai & 161 & 43 & 159 & 35 & 153 & 32 \\
\hline Puncak Jaya & 170 & 28 & 182 & 30 & 188 & 30 \\
\hline Mimika & 282 & 30 & 294 & 32 & 305 & 33 \\
\hline BovenDigoel & 158 & 31 & 167 & 33 & 175 & 32 \\
\hline Mappi & 190 & 35 & 203 & 36 & 214 & 37 \\
\hline Asmat & 154 & 25 & 151 & 27 & 153 & 28 \\
\hline Yahukimo & 221 & 43 & 231 & 45 & 259 & 47 \\
\hline Pegunungan Bintang & 183 & 17 & 202 & 19 & 217 & 21 \\
\hline Tolikara & 185 & 54 & 191 & 54 & 196 & 53 \\
\hline Sarmi & 121 & 27 & 125 & 28 & 126 & 29 \\
\hline Keerom & 165 & 15 & 166 & 16 & 170 & 17 \\
\hline Waropen & 115 & 14 & 123 & 14 & 130 & 15 \\
\hline Supiori & 94 & 23 & 96 & 22 & 99 & 21 \\
\hline Mamberamo Raya & 111 & 26 & 118 & 27 & 123 & 27 \\
\hline Nduga & 139 & 93 & 144 & 89 & 151 & 105 \\
\hline Lanny Jaya & 206 & 56 & 209 & 35 & 231 & 38 \\
\hline Mamberamo Tengah & 174 & 46 & 204 & 51 & 224 & 58 \\
\hline Yalimo & 181 & 92 & 133 & 152 & 94 & 164 \\
\hline Puncak & 226 & 33 & 240 & 36 & 274 & 43 \\
\hline Dogiyai & 171 & 61 & 174 & 75 & 180 & 89 \\
\hline Deiyai & 180 & 41 & 128 & 63 & 90 & 72 \\
\hline Intan Jaya & 124 & 73 & 200 & 46 & 258 & 38 \\
\hline Kota Jayapura & 390 & 24 & 387 & 25 & 391 & 26 \\
\hline Provinsi Papua & 187 & 26 & 191 & 27 & 196 & 28 \\
\hline Sumberyyyyyyyy$:$ BPs Papa & & & & & \\
\hline
\end{tabular}

Sumber : BPS Papua, 2015 (data diolah) 
Lampiran 3. Rata-Rata Lama Sekolah Dan Angka Partisipasi Murni Di Provinsi Papua Tahun 2012-2014

\begin{tabular}{|l|c|c|c|c|c|c|}
\hline \multirow{2}{*}{ Kabupaten/Kota } & \multicolumn{3}{|c|}{ RLS (tahun) } & \multicolumn{3}{c|}{ APM (\%) } \\
\cline { 2 - 7 } & $\mathbf{2 0 1 2}$ & $\mathbf{2 0 1 3}$ & $\mathbf{2 0 1 4}$ & $\mathbf{2 0 1 2}$ & $\mathbf{2 0 1 3}$ & $\mathbf{2 0 1 4}$ \\
\hline Merauke & 7.88 & 8.03 & 8.23 & 66.76 & 46.43 & 77.22 \\
\hline Jayawijaya & 4.31 & 4.36 & 4.39 & 77.08 & 40.16 & 78.61 \\
\hline Jayapura & 9.05 & 9.33 & 9.41 & 81.32 & 51.82 & 76.33 \\
\hline Nabire & 8.80 & 8.87 & 9.45 & 76.87 & 33.24 & 73.78 \\
\hline Yapen Waropen & 8.32 & 8.37 & 8.68 & 85.00 & 48.72 & 83.67 \\
\hline Biak Namfor & 8.93 & 8.99 & 9.61 & 79.00 & 54.51 & 76.47 \\
\hline Paniai & 3.66 & 3.73 & 3.74 & 76.86 & 43.75 & 79.51 \\
\hline Puncak Jaya & 2.53 & 2.86 & 3.04 & 78.56 & 36.38 & 46.94 \\
\hline Mimika & 8.75 & 8.83 & 9.30 & 77.23 & 37.57 & 80.28 \\
\hline Boven Digoel & 7.24 & 7.47 & 7.50 & 77.85 & 40.81 & 51.65 \\
\hline Mappi & 5.71 & 5.92 & 5.96 & 87.14 & 26.51 & 26.68 \\
\hline Asmat & 4.28 & 4.33 & 4.34 & 76.715 & 33.82 & 66.145 \\
\hline Yahukimo & 2.94 & 3.78 & 3.97 & 74.36 & 37.03 & 78.27 \\
\hline Pegunungan Bintang & 1.76 & 1.88 & 1.97 & 81.30 & 42.70 & 79.10 \\
\hline Tolikara & 2.88 & 3.00 & 3.04 & 81.97 & 45.68 & 78.04 \\
\hline Sarmi & 7.00 & 7.27 & 7.89 & 77.27 & 37.74 & 39.74 \\
\hline Keerom & 5.52 & 6.45 & 6.57 & 77.22 & 47.66 & 37.41 \\
\hline Waropen & 8.40 & 8.50 & 8.53 & 77.25 & 53.42 & 83.91 \\
\hline Supiori & 7.78 & 8.06 & 8.11 & 76.55 & 47.63 & 63.41 \\
\hline Membramo Raya & 4.33 & 4.42 & 4.44 & 78.77 & 49.77 & 71.84 \\
\hline Nduga & 0.49 & 0.60 & 0.63 & 65.07 & 30.81 & 23.40 \\
\hline Lanny Jaya & 2.35 & 2.55 & 2.60 & 72.02 & 47.70 & 59.92 \\
\hline Mamberamo Tengah & 2.15 & 2.18 & 2.40 & 72.79 & 42.74 & 75.88 \\
\hline Yalimo & 1.78 & 1.80 & 2.07 & 71.02 & 37.11 & 77.17 \\
\hline Puncak & 1.37 & 1.40 & 1.43 & 70.65 & 42.13 & 74.15 \\
\hline Dogiyai & 4.44 & 4.76 & 4.87 & 69.69 & 53.72 & 69.77 \\
\hline Intan Jaya & 2.09 & 2.16 & 2.32 & 70.41 & 32.13 & 50.46 \\
\hline Deiyai & 2.51 & 2.87 & 2.95 & 70.12 & 37.11 & 71.45 \\
\hline Kota Jayapura & 10.80 & 10.88 & 11.09 & 90.61 & 62.17 & 82.50 \\
\hline Provinsi Papua & 5.73 & 5.74 & 5.76 & 57.09 & 59.39 & 66.02 \\
\hline Sumber : BPS Papua & $2015)$ & & & & & \\
\hline
\end{tabular}

Sumber : BPS Papua (2015) 